Relationship of Porosity and Permeability to Petrology of the Madison Limestone in Rock Cores from Three Test Wells in Montana and Wyoming

GEOLOGICALSURVEY PROFESSIONAL PAPER 1273-C 
Relationship of Porosity and Permeability to Petrology of the Madison Limestone in Rock Cores from Three Test Wells in Montana and Wyoming

By PAUL A. THAYER

GEOLOGY AND HYDROLOGY OF THE MADISON LIMESTONE AND ASSOCIATED ROGKS IN PARTS OF MONTANA, NEBRASKA, NORTH DAKOTA, SOUTH DAKOTA, AND WYOMING

G E O L O I C A L S U R V E Y P R O F E S I O N A L P A P E R 127 3-C

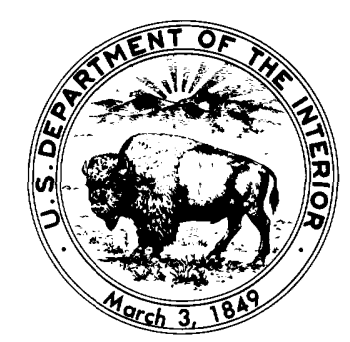


UNITED STATES DEPARTMENT OF THE INTERIOR

JAMES G. WATT, Secretary

GEOLOGICAL SURVEY

Dallas L. Peck, Director

Library of Congress Cataloging in Publication Data

Thayer, P. A.

Relationship of Porosity and Permeability to Petrology of the Madison Limestone in Rock Cores from Three Test Wells in Montana and Wyoming.

(Geological Survey Professional Paper ; 1273-C)

Bibliography, $p$.

1. Limestone-Montana. 2. Limestone-Wyoming 3. Borings-Montana. 4. Borings-Wyoming. 5. Geology, Stratigraphic-Paleozoic. I. Title. II. Series. QE471.15.L5T45 $1982 \quad 552 ' .4 \quad 82-600121$

For sale by the Distribution Branch, U.S. Geological Survey, 604 South Pickett Street, Alexandria, VA 22304 


\section{CONTENTS}

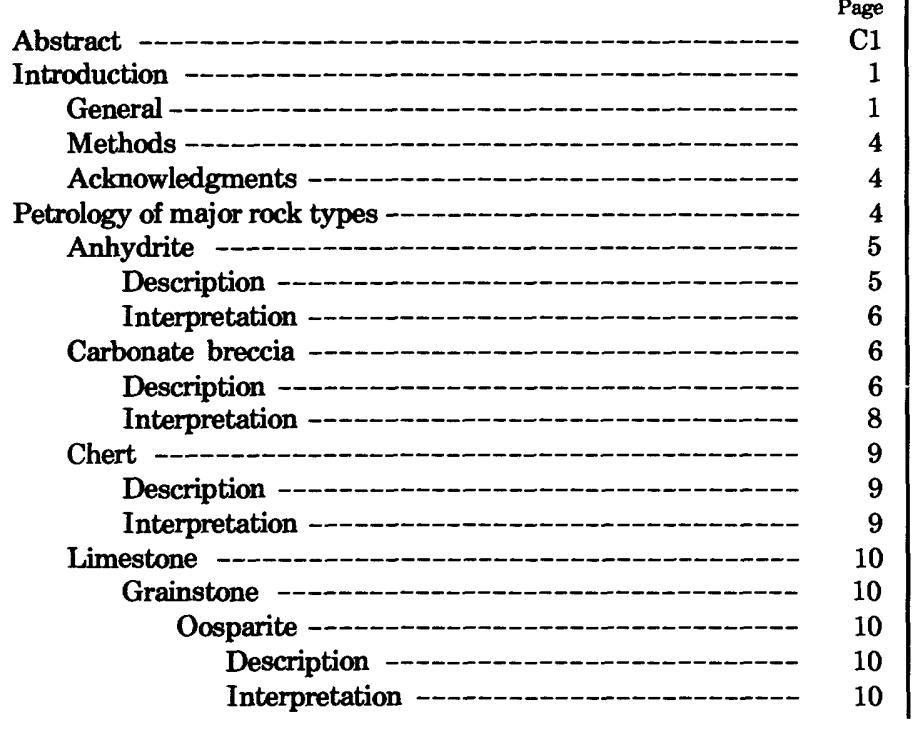

\begin{tabular}{|c|c|c|}
\hline Page & & \\
\hline $\mathrm{C} 1$ & Packstone-wackestone - & $\mathrm{C} 12$ \\
\hline 1 & Biomicrite --_-_- & 12 \\
\hline 1 & Description -----1- & 12 \\
\hline 4 & Interpretation - & 13 \\
\hline 4 & Carbonate mudstone - & 13 \\
\hline 4 & Micrite and fossiliferous micrite & 13 \\
\hline 5 & - & 13 \\
\hline 5 & Interpretation - & 14 \\
\hline 6 & Dolomite - & 14 \\
\hline 6 & Intertidal-supratidal dolomite -- & 14 \\
\hline 6 & omicrite --_--- & 14 \\
\hline 8 & 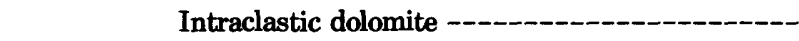 & 14 \\
\hline 9 & te with relict allochems - - & 15 \\
\hline 9 & 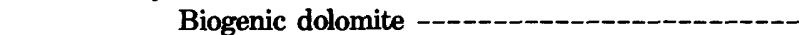 & 15 \\
\hline 9 & nite without relict allochems -------- & 15 \\
\hline 10 & 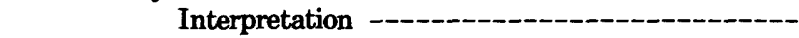 & 16 \\
\hline 10 & - - - & 17 \\
\hline 10 & --_---_- & 18 \\
\hline 10 & - & 24 \\
\hline 10 & --_--- & $\mathbf{2}^{\prime}$ \\
\hline
\end{tabular}

\section{ILLUSTRATIONS}

age

12

\section{2}

13

13

13

14

14

14

14

15

15 15 17 18 24

[Plates are in pocket]

PLATES 1-3. Diagrams showing relation of porosity and permeability to rock type and grain size in selected cores from U.S.

Geological Survey test wells

1. Test well 1

2. Test well 2

3. Test well 3

Figure 1. Map showing location of study area -

2. Examples of well-log patterns and lithology of Madison Group marker units -

3. Computed percentages of calcite and dolomite for 358 samples of Madison Limestone carbonate rocks -4-6. Photographs showing:

4. Medium crystalline, subhedral anhydrite with pile-of-brick fabric, middle of the Madison Limestone interval M-7 to M-8.5 -

5. Limestone breccia with closely packed, angular to subrounded clasts of micrite, biomicrite, and pelmicrite, top of Madison Limestone interval M-8.5 to M-12 -

6. Bedded chert with irregularly shapped stringers and patches of darker dolomite, base of Madison Limestone interval $\mathrm{M}-1$ to $\mathrm{M}-3$

7. Map showing present-day structural features, Western Interior, United States -

8-13. Photographs showing:

8. Medium-grained, well-sorted oosparite with filled mesointerooid porosity, Madison Limestone interval M-12 to Mc -

9. Medium-grained, poorly sorted biomicrite (wackestone), Madison Limestone interval M-12 to Mc -_--_-----

10. Thinly laminated dolomicrite of inferred supratidal origin, near top of Madison Limestone interval M-7 to M-8.5 --

11. Medium crystalline biogenic dolomite, base of Madison Limestone interval M-1 to M-3

12. Intercrystalline porosity in finely crystalline dolomite, Madison Limestone interval M-3 to M-7 -...-.......-

13. Moldic porosity in finely crystalline replacement dolomite with xenotopic fabric, Madison Limestone interval M-3 to M-7

14. Idealized Madison Limestone shallowing-upward (regressive) peritidal sequence 
15-19. Graphs showing:

15. Cumulative curve of porosity of all Madison Limestone samples

16. Cumulative curve of horizontal permeability of all Madison Limestone samples

17. Porosity-permeability characteristics of limestones in the Madison Limestone -

19. Porosity-vertical permeability characteristics of Madison Limestone replacement dolomites --

20. Scatterplot of mean dolomite crystal size versus porosity for Madison Limestone crystalline dolomites --_-_- 24

21. Scatterplot of standard deviation (sorting) of dolomite crystal size versus porosity for Madison Limestone dolomites -----22-24. Graphs showing:

22. Mean dolomite crystal size versus horizontal permeability for Madison Limestone crystalline dolomites --_._-_-_

23. Percent anhydrite versus percent porosity for Madison Limestone crystalline dolomites --_-_-_-_-_-_-_-_- 27

24. Percent porosity versus depth in feet below ground surface for Madison Limestone crystalline dolomites --..----

\section{TABLES}

TABLE 1. Generalized correlation chart of paleozoic rocks [in pocket]

2. Thickness and percentage of Madison Limestone marker intervals cored in U.S. Geological Survey test wells 1, 2, and 3 --

3. Percentage of major rock types in the Madison Limestone in U.S. Geological Survey test wells 1, 2, and 3 -

4. Porosity and permeability of rock types in the Madison Limestone

5. Percentage of major rock types in cores of Madison Limestone marker intervals in U.S. Geological Survey test wells 1,2 , and 3 --..--_-

6. Porosity and permeability of cores in Madison Limestone marker intervals in U.S. Geological Survey test wells 1,2 , and 3

\section{METRIC CONVERSION TABLE}

\author{
Multiply inch-pound units \\ inches (in) \\ inches \\ feet (ft) \\ feet \\ square miles $\left(\mathrm{mi}^{2}\right)$
}

$B y$
2.54
25.4
0.3048
30.48
2.59001

To find metric units
centimeters $(\mathrm{cm})$
millimeters $(\mathrm{mm})$
meters $(\mathrm{m})$
centimeters
square kilometers $\left(\mathrm{km}^{2}\right)$ 


\section{GLOSSARY OF PETROGRAPHIC TERMS}

Allochem. One of several varieties of discrete and organized carbonate aggregates that serve as the coarser framework grains in most mechanically deposited limestone.

Allochthonous. Formed elsewhere than in its present place, of foreign origin.

Anhedral. A crystal that has failed to develop its own faces or that has a rounded or indeterminate form produced by the crowding of adjacent mineral grains during crystallization.

Aphanocrystalline. A texture of a carbonate sedimentary rock having crystals whose diameters are extremely fine.

Authigenic. Rock constituents and minerals that have not been transported or that crystallized locally at the spot where they are now found.

Bioclast. A single fossil fragment.

Biogenic. Produced directly by the physiological activities of either plants or animals.

Biomicrite. A limestone consisting of a variable proportion of skeletal debris and carbonate mud.

Biopelite. An organic pelite.

Biopelmicrite. A limestone intermediate in content between biomicrite and pelmicrite.

Biopelsparite. A limestone intermediate in content between biosparite and pelsparite.

Dedolomite. Calcite pseudomorphous after domomite.

Dolomicrite. A sedimentary rock consisting of clay-sized dolomite crystals, a lithified dolomite mud.

Enterolithic. A sedimentary structure consisting of ribbons of intestinelike folds that originate through chemical changes involving increases or decreases in the volume of the rock.

Equigranular. (Homogramular) the texture of a rock having crystals of the same or nearly the same size.

Euhedral. A mineral grain that is completely bounded by its own faces, and whose growth during crystallization was not restrained or interfered with.

Fenestra. A shrinkage pore, or an open space in the rock.

Grainstone. A mud-free grain-supported, carbonate sedimentary rock.

Intertidal. (Littoral) the ocean environment between high water and low water.

Intraclast. A component of a limestone, representing a torn-up and reworked fragment of a penecontemporaneous sediment.

Intercrystal porosity. Porosity between equant, equal-sized crystals.

Interparticle porosity. The porosity between particles in a rock.

Meso-. A prefix meaning middle.
Micrite. The semi-opaque crystalline matrix of limestones, consisting of chemically precipitated carbonate mud.

Microspar. Calcite matrix in limestones, occurring as uniformly sized crystals.

Moldic porosity. Porosity resulting from the removal by solution, of an individual constituent of a rock.

Neomorphism. The transformations between one mineral and itself or a polymorph, by the processes of inversion, recrystallization, and strain recrystallization.

Oolite. A limestone, made up chiefly of ooliths cemented together.

Oolith. One of the small round accretionary bodies in a sedimentary rock.

Oomicrite. A limestone containing ooliths in a carbonate-mud matrix (micrite).

Oosparite. A limestone containing ooliths in which the sparrycalcity cement is more abundant that the carbonate-mud matrix (micrite).

Packstone. A sedimentary carbonate rock whose granular material is arranged in a self-supporting framework, yet also contains some matrix of calcareous mud.

Pelmicrite. A limestone consisting of a variable proportion of pellets and carbonate mud (micrite).

Peloid. An allochem composed of micrite.

Peritidal. Depositional environments in a zone from somewhat above highest storm or spring tides to somewhat below lowest tides.

Phi mean diameter $(\phi)$. A logarithmic mean diameter. The negative logarithm to the base 2 of the average grain size.

Pseudomorph. A mineral whose outward crystal form is that of another mineral species.

Pseudosparite. A limestone consisting of relatively large, clear calcite crystals that have developed by recrystallization.

Quartzine. Chalcedony characterized by fibers having a positive crystallographic elongation.

Sabkha. A supratidal environment under arid to semiarid conditions on restricted coastal plains just above normal high-tide level.

Sparry calcite. Clean, coarse-grained calcite crystal.

Subhedral. A mineral grain that is bounded partly by its own faces and partly by surfaces formed against preexisting grains. -

Supratidal. Pertaining to the shore area marginal to the littoral zone, just above high-tide level.

Syntaxy. Similar crystallographic orientation in a mineral grain and its overgrowth.

Wackestone. A mud-supported carbonate sedimentary rock containing more than 10 percent grains or particles. 



\title{
RELATIONSHIP OF POROSITY AND PERMEABILITY TO PETROLOGY OF THE MADISON LIMESTONE IN ROCK CORES FROM THREE TEST WELLS IN MONTANA AND WYOMING
}

\author{
By PAUL A. THAYER
}

\begin{abstract}
The need for large quantities of energy has created interest in the Fort Union coal region of the Northern Great Plains. Extensive development of this coal, which may include onsite steam-power generation, gasification, liquefaction, and slurry pipeline transport of the coal from the region, would place an intense demand on the region's limited streamflow. Paleozoic rocks that underlie the Fort Union coal region might supply, at least on a temporary basis, a significart part of the water required for coal development. The area of study covers approximately 200,000 square miles and includes eastern Montana, western North Dakota and South Dakota, northeastern Wyoming, and northwestern Nebraska.

The Madison Limestone, or Group, where it is divided, consists of a lower argillaceous limestone (Lodgepole Limestone); a middle unit of fossiliferous carbonate rock (Mission Canyon Limestone); and an upper unit of anhydrite, halite, and interbedded carbonate rock and shale (Charles Formation). The total section is made up of numerous cyclic, marker-defined units. The Madison Limestone was subdivided into units bounded by "marker beds" that consist of thin and widespread shaly carbonate or dark shale recognizable in the subsurface on geophysical logs. The five marker beds used for regional correlation purposes are as follows: $M-1$ represents the base of the Madison Limestone; M-3 is near the Kinderhookian-Osagean boundary; M-7 and M-8.5 fall within the Osagean; and M-12 is near the Osagean-Meramecian boundary. The top of the Madison Limestone is the Mc marker.

Petrology and petrography of the Madison Limestone and associated rocks were studied from cores taken in three test wells of the U.S. Geological Survey. Six major rock types are recognized within cored intervals of the three test wells. Dolomite forms twothirds of the total and limestone about one-fifth. The rest consists of anhydrite, carbonate breccia, carbonate mudstone, and chert.

Crystalline dolomite is the only abundant rock type in wells 1,2 , and 3 that has high enough porosity and permeability to provide significant yields of water. Crystalline dolomites not associated with evaporites may have formed by some sort of meteoric water-sea water mixing process in the subsurface shoreline environment by recrystallization of mud-rich limestones.

Porosity and permeability values of all cored intervals of the Madison Limestone were determined. Mean porosity for the Madison Limestone is 8.4 percent, and mean permeability is 15.8 millidarcies (mD). Because the Madison Limestone is relatively heterogeneous, permeability has a wide range in value.
\end{abstract}

\section{INTRODUCTION}

GENERAL

Energy, its use and conservation, and the need for alternative sources to supply large quantities of it have caused government and industry to focus attention on the Fort Union coal region of the Northern Great Plains, where a major part of the United States' coal reserves occur (fig. 1). Extensive development of this coal, which may include onsite steam-power generation, gasification, liquefaction, and slurry-pipeline transport of the coal outside this region, would place a heavy demand on the region's limited water resources.

Streamflow in the region is poorly distributed. Its use for coal development in parts of the region would require only storage reservoirs and distribution systems, whereas in the rest of the region streamflow is already fully appropriated and its use would deprive present users of their supply.

Paleozoic rocks, which include the Madison Limestone, its equivalents, and associated rocks underlie the Fort Union coal region and adjacent areas in Montana, North Dakota, South Dakota, Nebraska, and Wyoming. Aquifers in the rocks of Paleozoic age, including the Madison Limestone, might supply a significant percentage of the water required for coal development, at least on a temporary basis. The purpose of the Madison Limestone Project, begun during 1976, is to evaluate the quantity and quality of water in these aquifers. This report, which stems from the Madison Limestone Project, describes selected core samples from three test holes and the relation of the samples to porosity and permeability of facies of the aquifers.

The project area covers approximately $200,000 \mathrm{mi}^{2}$ in eastern Montana, western North Dakota and South Dakota, a small part of northwestern Nebraska, and 


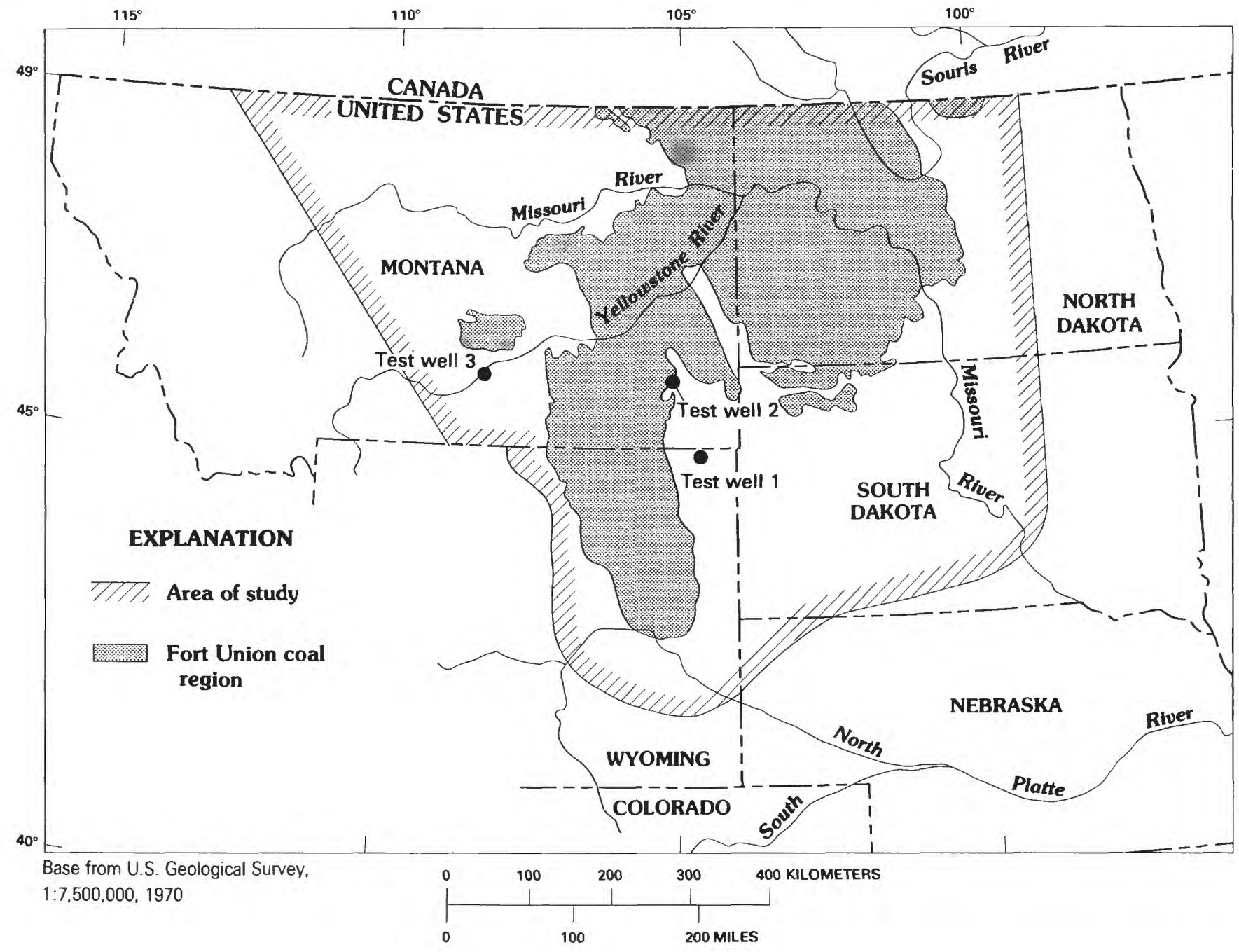

Figure 1.-Location of study area.

northeastern Wyoming (fig. 1). The areas of greatest interest, however, are the Powder River basin of Montana and Wyoming and the area surrounding the Black Hills in South Dakota, Wyoming, and adjacent North Dakota, Montana, and Nebraska. The Madison Limestone crops out in the mountainous areas; however, in much of the region it ranges in depth from 2,000 to $16,000 \mathrm{ft}$ below land surface.

The Madison Limestone is undivided in parts of the project area and is divided into formations in other parts of the area. Where it is divided into formations, it is called the Madison Group (table 1). For consistency, however, the term Madison Limestone is used in this report. Generally, the Madison Limestone, in ascending order, consists of thin- to medium-bedded argillaceous to shaly or silty, in places cherty, limestone; thick- to massive-bedded fossiliferous to oolitic carbonate rock, and anhydrite and halite interbedded with carbonate rock and shale. These gross facies intertongue, and the total section is made up of numerous cyclic, markerdefined units that incorporate variable amounts of the main rock facies. In this study, the Madison Limestone was subdivided into 13 units for the purposes of establishing a correlation framework (fig. 2). Each correlation unit is bounded by marker beds that consist of thin and widespread shaly carbonate or dark shale intervals that are recognizable in the subsurface on gamma ray neutron or gamma ray sonic logs, and are traceable throughout large parts of the project area. Similar marker beds characterize the Madison Limestone and its equivalents throughout most of the Rocky Mountain area. In general, log definition of the marker beds is best expressed in the main part of the Williston basin; however, most of them can be traced with reasonable confidence throughout Montana, Wyoming, and South Dakota. The five marker beds that have proven to be the most useful for regional correlation purposes are shown in figure 2. Marker M-1 represents the base of 
HUNT NO. 1 NPRR

T. 5 N.-R. 59 E.-SEC. 11, MONTANA

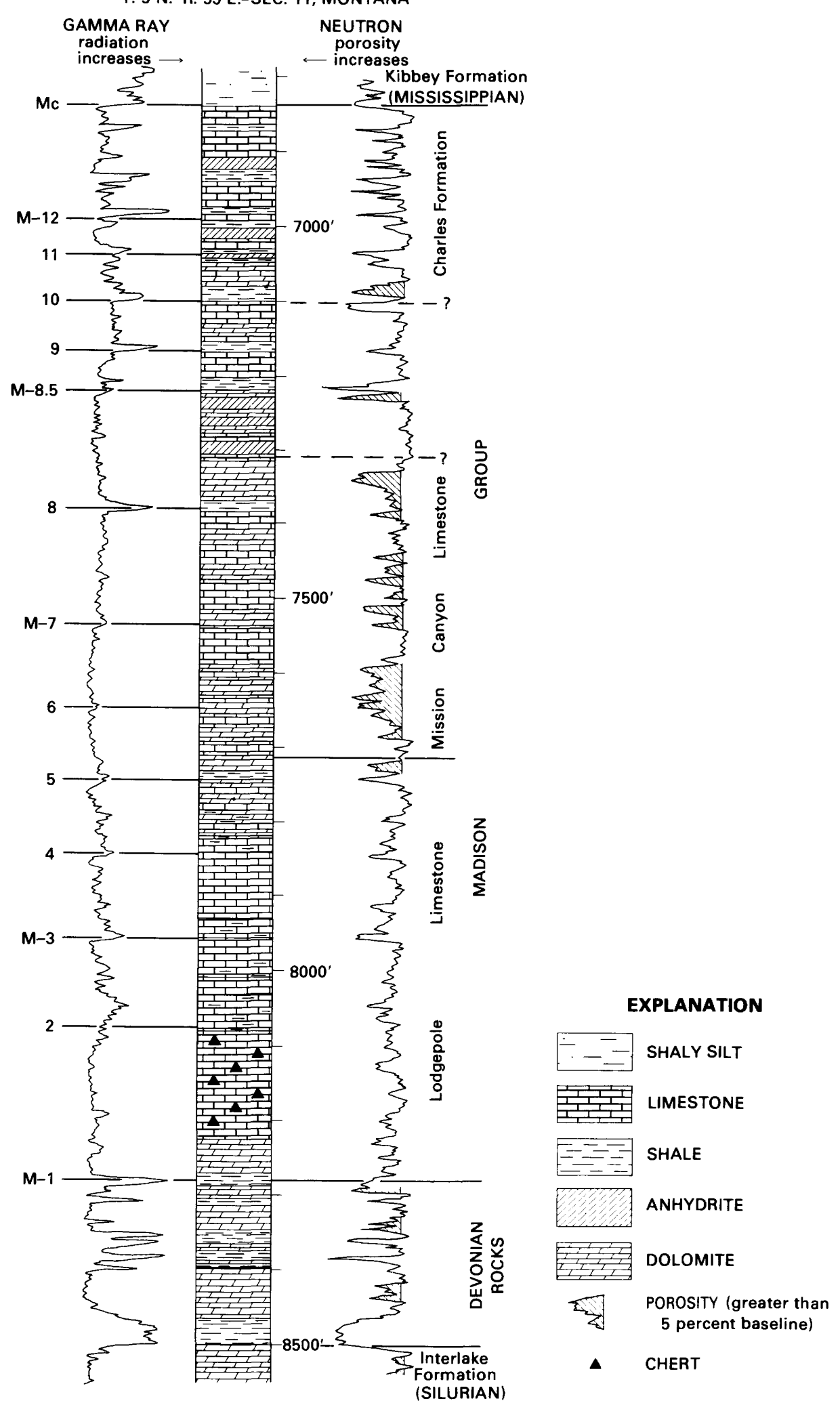

FIGURE 2.-Examples of well-log patterns and lithology of Madison Limestone marker units. 
the Madison Limestone; $\mathrm{M}-3$ is near the Kinderhookian and Osagean boundary; M-7 and M-8.5 fall within the Osagean; and M-12 is near the Osagean and Meramecian boundary. The top of the Madison Limestone is designated as the Mc marker. The sections of core for each of the Madison Limestone test wells are identified by their respective marker beds.

Petrology and petrography of the Madison Limestone and associated rocks were studied from cores taken in three test wells of the U.S. Geological Survey (fig. 1), and this information was related to the origin and distribution of pore systems in these rocks. The main objectives were: (1) to describe and delineate petrographic microfacies; (2) to determine if variations in carbonate facies, which reflect differences in original depositional environments and fossil communities, control development of primary and secondary pore systems; (3) to determine the effects of diagenesis and dolomitization on porosity and permeability; and (4) to ascertain what lithologic and other characteristics now control porosity and permeability.

\section{METHODS}

In this study, 30 cored sections of Madison Limestone and adjacent formations of Pennsylvania and Devonian age from U.S. Geological Survey test wells 1, 2, and 3 were examined in detail. Total thickness of the cored sections studied is $1,062 \mathrm{ft}$, of which $913 \mathrm{ft}$ is from the Madison Limestone; $51 \mathrm{ft}$ is from Pennsylvanian formations; and $98 \mathrm{ft}$ is from Devonian formations. The cored intervals studied within each well are shown on plates 1 , 2 , and 3. The total marker interval thicknesses, as well as the thickness and percentage of each interval cored are listed by well in table 2 . Porosity and permeability values were measured on 300 core plugs cut parallel to bedding. In addition, whole-core porosity and permeability were determined on 36 Madison Limestone cores. Grain density was measured on 125 of the core plugs.

The relative abundance of various porosity types in rock slabs and thin sections was estimated by visual inspection, using the porosity classification of Choquette and Pray (1970). Where more than one porosity type was present, the abundance of each type was noted as a percentage of the total. Average pore size was determined by measuring the diameters of 10 randomlyselected equant pores per thin section.

\section{ACKNOWLEDGMENTS}

This study was conducted by the author with assistance from personnel of the U.S. Geological Survey, Central Region, and the district offices in Montana, North Dakota, South Dakota, and Wyoming. The work was under the general supervision of Elliott Cushing. This report utilizes the subsurface geology and correlations made by Donald L. Brown and the chronostratigraphic correlations established by James A. Peterson. Necip Güven, Texas Tech University, did most of the X-ray diffraction analyses of samples from wells 1 and 2; he also did the electron microscopy of clay minerals from these wells. David Chastain of the University of North Carolina at Wilmington performed the X-ray and insoluble residue analyses for well 3 ; he also assisted with drafting and photographic work. Porosity, permeability, and grain density determinations were done by Core Laboratories, Denver, Colorado. The University of North Carolina at Wilmington provided research facilities and computer time.

\section{PETROLOGY OF MAJOR ROCK TYPES}

Six major rock types are recognized in the Madison Limestone and adjacent formations within the cored intervals of test wells 1,2 , and 3 . The overall percentage of major rock types in the Madison Limestone in the three wells, and the average for all three wells is given in table 3. Dominant rock types in the cored intervals of the adjacent formations are dolomite and sandstone. A

TABLE 2.-Thickness and percentage of Madison Limestone marker intervals cored in U.S. Geological Survey test wells 1, 2, and 3

\begin{tabular}{|c|c|c|c|c|c|c|}
\hline \multirow[b]{2}{*}{ Marker intervals } & \multicolumn{2}{|c|}{ Test well 1} & \multicolumn{2}{|c|}{ Test well 2} & \multicolumn{2}{|c|}{ Test well 3} \\
\hline & $\begin{array}{c}\text { Core } \\
\text { thickness } \\
\text { (ft) }\end{array}$ & $\begin{array}{l}\text { Percent of } \\
\text { interval } \\
\text { cored }\end{array}$ & $\begin{array}{c}\text { Core } \\
\text { thickness } \\
\text { (ft) }\end{array}$ & $\begin{array}{l}\text { Percent of } \\
\text { interval } \\
\text { cored }\end{array}$ & $\begin{array}{c}\text { Core } \\
\text { thickness } \\
\text { (ft) }\end{array}$ & $\begin{array}{c}\text { Percent of } \\
\text { interval } \\
\text { cored }\end{array}$ \\
\hline $\mathrm{M}-12$ to $\mathrm{Mc}-$ & -- & -- & 55 & 100 & -- & -- \\
\hline $\mathrm{M}-8.5$ to $\mathrm{M}-12$ & -- & -- & 130 & 65 & -- & -- \\
\hline $\mathrm{M}-8.5$ to $\mathrm{Mc}$ & 111 & 62 & -- & -- & 64 & 34 \\
\hline $\mathrm{M}-7$ to $\mathrm{M}-8.5$ & 64 & 37 & 37.2 & 13 & 63 & 26 \\
\hline M-3 to M-7 & 99.5 & 48 & 54 & 16 & 30 & 8 \\
\hline M-1 to M-3 - & 70 & 29 & 95.5 & 32 & 60 & 22 \\
\hline
\end{tabular}


plot of calcite-dolomite mixtures in carbonate rocks of the Madison Limestone shows a markedly bimodal distribution, with most samples being either limestone (22 percent) or dolomite (45 percent) (fig. 3). About 10 percent of the carbonate rock is dolomitic limestone and 33 percent is calcitic dolomite.

Some of the rock types (such as crystalline dolomite) are relatively uniform in character and occur within all stratigraphic units of the Madison Limestone. Most, however, include several subtypes and are typically limited to certain wells or marker units. Several of the major rock types tend to be cyclically arranged within a given vertical section; the origin and environmental significance of these cycles will be discussed in another section. Many of the rock types display diagenetic features and porosity types that are directly related to variations in depositional facies.

The carbonate rock classification used herein is that of Folk (1959, 1962). Where appropriate, Dunham's (1962) classification has been used to differentiate grainsupported and matrix-supported rocks. The fabric terminology for crystalline sedimentary rocks is from Friedman (1965). Bed-thickness terms are adopted from Ingram (1954), and bed-shape terms are those of Campbell (1967).

TABLE 3.-Percentage of major rock types in the Madison Limestone in U.S. Geological Survey test wells 1, 2, and 3

\begin{tabular}{|c|c|c|c|c|}
\hline Rock type & Test well $1^{\prime}$ & Test well $2^{12}$ & Test well $3^{\prime}$ & $\begin{array}{l}\text { Average of } \\
3 \text { wells }^{13}\end{array}$ \\
\hline Anhydrite -- & -- & 7.3 & 2.7 & 4.2 \\
\hline Carbonate breccia --_---- & 4.8 & 3.7 & 1.2 & 2.8 \\
\hline Chert - - & 2.4 & 3.7 & 8.2 & 4.7 \\
\hline Dolomite ---_-_-_-_ & 80.7 & 50.9 & 77.9 & 66.6 \\
\hline \multicolumn{5}{|l|}{ Limestone } \\
\hline Grainstone -- & 6.0 & 10.9 & 9.1 & 9.2 \\
\hline Packstone-wackestone & 2.5 & 18.1 & 0.9 & 8.7 \\
\hline Carbonate mudstone ------ & 3.6 & 4.8 & -- & 3.6 \\
\hline
\end{tabular}

${ }^{1}$ The limestones include varying percentages of dolomitic limestone.

${ }^{2} 0.6$ percent is quartz sandstone.

${ }^{3} 0.2$ percent is quartz sandstone.

\section{ANHYDRITE}

\section{DESCRIPTION}

Layers of nodular anhydrite occur chiefly in the M-7 to $M-8.5$ interval of wells 2 and 3 and in the M-8.5 to M-12 interval of well 2. Anhydrite is also found in subordinate amounts in the M-3 to M-7 interval of wells 1 and 2. Small, isolated nodules of anhydrite occur sporadically throughout the Madison Limestone.

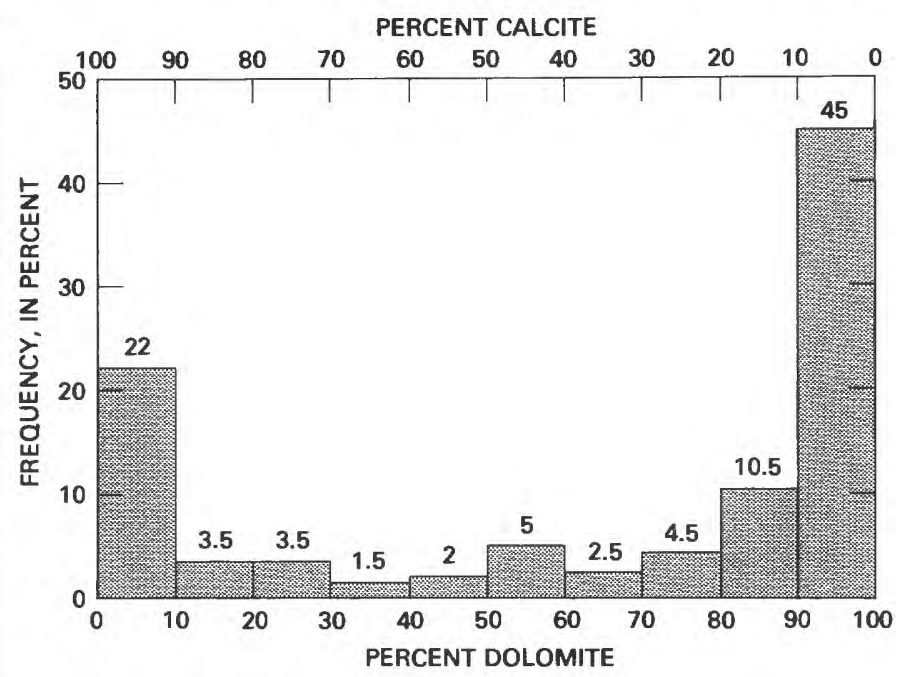

FIGURE 3.-Computed percentages of calcite and dolomite for 358 samples of Madison Limestone carbonate rocks.

Anhydrite is typically very light gray or light gray, massive, and displays mosaic of "chicken-wire" structure, owing to the presence of thin stringers of darkercolored aphanocrystalline dolomite. Anhydrite beds are typically bounded by aphanocrystalline or very finely crystalline dolomite; the contacts are generally sharp. Often, the underlying dolomite displays thin laminations that are either even and parallel or wavy and parallel. As will be shown later, these dolomites are considered to be of primary supratidal or intertidal origin.

Most of the anhydrite is medium crystalline (fig. 4), but grain size commonly varies from aphanocrystalline to coarsely crystalline. The anhydrite is equigranular with most grains being subhedral. Average composition of 15 anhydrite samples is: anhydrite, 75.1 percent; dolomite, 17.0 percent; chalcedony, 1.5 percent; quartz, 2.1 percent; sparry calcite, 2.3 percent; voids, 1.8 percent; and opaque minerals, 0.2 percent.

The dolomite within anhydrite is typically aphanocrystalline or very finely crystalline. Silica minerals are of variable size and texture. Euhedral megaquartz greater than $20 \mu \mathrm{m}$ (micrometers) often with abundant anhydrite inclusions, is the most common quartz type. Prismatic crystals are generally terminated by a single set of rhomb faces; some, however, are doubly terminated. A few crystals consist of a prism terminated by three faces of a single rhomb, giving rise to a "cubic" appearance. Radially undulose megaquartz (Millikan, 1979 , p. 246), consisting of elongate crystal aggregates with fanlike extinction surrounding a core of anhydrite, also occurs. Chalcedony and quartizine (length-slow chalcedony) most commonly occur as isolated or interlocking spherules and also as cavity fillings; they rarely contain anhydrite inclusions. 


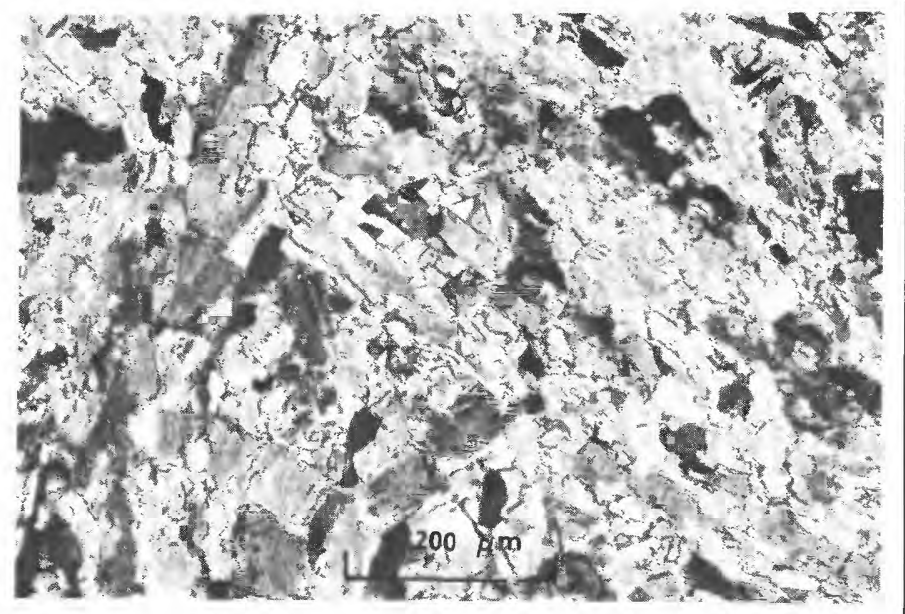

Figure 4.-Medium crystalline, subhedral anhydrite with pile-ofbrick fabric. Note straight and crenulated boundaries between individual laths. The holes (dark areas) were produced during their section preparation. Porosity is 0.4 percent and horizontal permeability is $0.06 \mathrm{mD}$. Middle of the Madison Limestone interval M-7 to M-8.5. Test well 3, depth $4603.6 \mathrm{ft}$. Crossed nicols.

The significance of these silica minerals is that identical types are found in carbonate rocks, especially dolomites, throughout the Madison Limestone, even where anhydrite is not now present. They thus record the existence of precursor evaporite minerals and indicate the presence of former sabkha environments (Folk and Pittman, 1971; Siedlecka, 1972; and Millikan, 1979).

Nodular anhydrite characteristically has low porosity and permeability. The mean value of measured porosity for 10 core plugs is 0.57 percent, the minimum value is 0.3 percent, and the maximum, 1.3 percent. Horizontal permeability measurements on four of these plugs range from less than $0.01 \mathrm{mD}$ (millidarcies) to a maximum of $0.06 \mathrm{mD}$, and have an average of $0.02 \mathrm{mD}$. Because of its low porosity and permeability, the bedded anhydrite where it is continuous, may act as a barrier for movement of water.

Anhydrite also occurs as a widespread accessory mineral in limestones and dolomites of the Madison Limestone. Three anhydrite types are recognized: (1) anhydrite veins; (2) pore-filling anhydrite; and (3) replacement anhydrite. Commonly, these anhydrite types are found concentrated near, and in close association with, bedded anhydrite.

\section{INTERPRETATION}

The "chicken-wire" and enterolithic structures of the nodular anhydrite, along with its crystal fabric and close association with laminated and algal dolomicrites strongly suggests an arid supratidal (sabkha) origin (Shearman, 1978; Till, 1978; Kendall, 1979). The anhydrite was precipitated from interstitial brines within the host sediment, and thus represents a diagenetic product formed beneath the sabkha surface rather than a primary precipitate formed on the sabkha surface (Murray, 1964). Studies in present-day coastal sabkhas, particularly Abu Dhabi, on the Arabian peninsula, indicate that anhydrite probably originates by secondary replacement of precursor gypsum crystals, which were originally present in the upper parts of the intertidal zone.

\section{CARBONATE BRECCIA}

\section{DESCRIPTION}

Carbonate breccias are present in the upper part of the Madison Limestone in all three wells. In test well 1, they occur at the top of the M-8.5 to M-12 interval, the top of the M-7 and M-8.5 interval, and the base of this M-7 interval. Breccias in well 2 occur within the M-12 to Mc interval, and at the top of the M-8.5 to M-12 interval. Carbonate breccia in well 3 is restricted to the M-8.5 to M-12 interval.

The breccia zones vary from about $2 \mathrm{ft}$ to a maximum of about $40 \mathrm{ft}$ in thickness at the base of the M-8.5 to Mc interval in well 1. The basal contacts are usually sharp and planar. The upper contacts are gradational with carbonate breccia grading upward through fractured carbonate into bedded, unfragmented, carbonate rock. Generally the breccias are well indurated and massively thick or very thick bedded. Thin beds of shaly carbonate, however, are sometimes present within the breccia sequence, especially in the uppermost part of the Madison Limestone in wells 1 and 2.

Apparent maximum clast size ranges from about 3 in. to about 12 in. In contrast, Sando (1974, p. 139) reports clasts as much as tens of feet in diameter from stratigraphically equivalent breccias at the north end of the Wind River Range in Wyoming. Because of the heterogeneous character of the breccias, average clast size is difficult to ascertain; most clasts, however, can be classified in the cobble and small boulder size range. Clast size does not systematically vary with respect to stratigraphic position. However, fractures in carbonates above the breccias are often widely spaced, giving the rocks an appearance of being composed of very large "clasts."

On the basis of clast composition, two types of carbonate breccia are recognized: dolomitic breccia and limestone breccia. Texture and color of the two types are nearly identical. Dolomitic breccias occur chiefly at the top of the Madison Limestone in wells 1 and 2, and 
in the M-8.5 to Mc interval in wells 1 and 3. Limestone breccias are found mainly at the top of the M-8.5 to M-12 and M-12 to Mc intervals in test well 2.

Dolomite breccias consist principally of angular dolomicrite and (or) dolomicrosparite clasts set in a matrix of crushed dolomicrite mixed with subordinate clay, quartz silt and sand, and opaque minerals. Near the top of the Madison Limestone in wells 1 and 2, the matrix is commonly iron oxide stained.

Limestone breccias are composed chiefly of micrite and microspar clasts embedded in a matrix of clay, fine carbonate, and quartz silt and sand (fig. 5). Near the top of the Madison Limestone the matrix is commonly stained by iron oxide minerals.

Although a large number of porosity and permeability determinations have been made on core plugs (table 4) taken from the breccias, these are not considered to be representative of the whole rock. Rather, it is more likely they represent porosity and permeability of the matrix or individual clasts. Only three whole-core analyses were done on the breccias, and the resultant values show considerable scatter. Porosity ranges from 1.5 to 18.5 percent and averages 7.1 percent. Only one horizontal permeability determination was made; it has a value of 13 millidarcies.

Breccia porosity is the dominant pore type in these rocks. Fracture, channel, and vug porosity types are also very common (plates 1,2 , and 3 ). In most instances, pores between clasts have been either reduced or filled with internal sediment and (or) cement, thus yielding

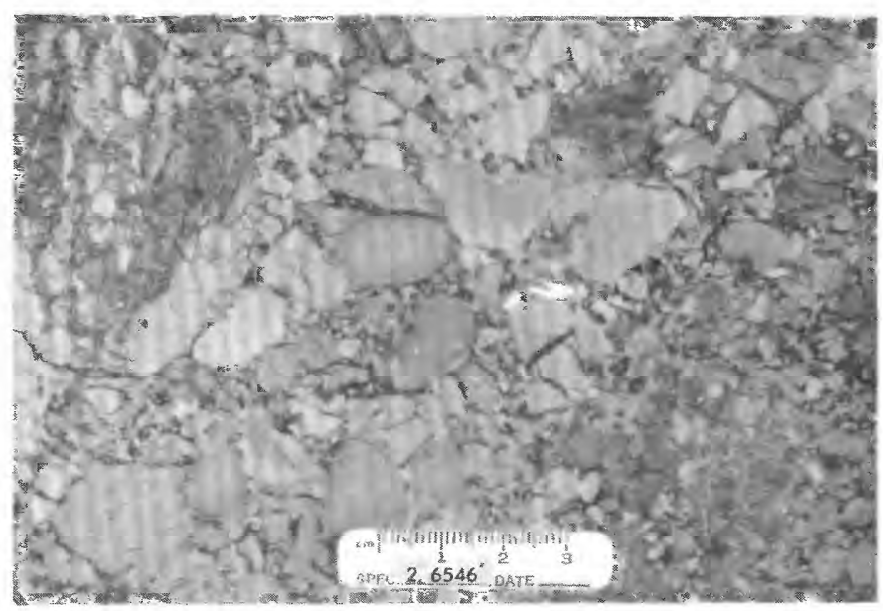

FIGURE 5.-Limestone breccia with closely packed, angular to subrounded clasts of micrite, biomicrite, and pelmicrite. The matrix is iron oxide-stained carbonate and clay with minor quartz silt. White specks in center are anhydrite. Porosity is 1.2 percent and horizontal permeability $0.2 \mathrm{mD}$. Top of Madison Limestone interval M-8.5 to M-12. Test well 2, depth 6,546 ft. Top of core is at left of photograph. Polished slab. Reflected light.

small overall porosity and permeability values. Most porosity is actually located within individual clasts, with the porosity type being determined by clast type.

Some of the breccias have secondary fracture porosity that evidently developed after lithification. Many of the fractures in these rocks show evidence of initial solution enlargement followed by later cement reduction; that is,

TABLE 4.-Porosity and permeability of rock types in the Madison Limestone [Numbers in parentheses (n) indicate number of samples tested]

\begin{tabular}{|c|c|c|c|c|c|c|c|c|c|c|c|c|}
\hline \multirow[b]{2}{*}{ Rock type } & \multicolumn{4}{|c|}{ Porosity } & \multicolumn{4}{|c|}{ Horizontal permeability } & \multicolumn{4}{|c|}{ Vertical permeability } \\
\hline & \multicolumn{2}{|c|}{ Mean (n) } & \multirow{2}{*}{$\begin{array}{c}\frac{\text { Minimum }_{\text {(percent) }}}{0.3} \\
0 .\end{array}$} & \multirow{2}{*}{$\begin{array}{c}\text { Maximum } \\
1.3\end{array}$} & \multicolumn{2}{|c|}{ Mean (n) } & $\underset{(m D)}{\operatorname{Minimum}}$ & Maximum & \multicolumn{2}{|c|}{ Mean (n) } & \multirow{2}{*}{$\begin{array}{c}\text { Minimum } \\
(\mathrm{mD}) \\
--\end{array}$} & \multirow{2}{*}{ Maximum } \\
\hline Anhydrite & 0.6 & (10) & & & 0.03 & (4) & 0.01 & 0.06 & -- & & & \\
\hline Carbonate breccia & 4.6 & (29) & 0.4 & 13.4 & 0.87 & (22) & 0.01 & 10.0 & 0.73 & (11) & $<0.01$ & 6.3 \\
\hline Bedded chert & 11.2 & (4) & 0.6 & 18.7 & 0.45 & (3) & 0.28 & 0.72 & -- & & -- & -- \\
\hline Oosparite & 3.4 & (9) & 0.6 & 7.0 & 0.07 & (6) & $<0.01$ & 0.22 & -- & & -- & -- \\
\hline Dolomitic oosparite & 4.8 & (5) & 2.5 & 7.2 & 0.24 & (4) & $<0.01$ & 0.76 & -- & & -- & - \\
\hline Biomicrite & 2.8 & (11) & 1.0 & 4.3 & 0.01 & (8) & $<0.01$ & 0.2 & 0.01 & (3) & $<0.01$ & 0.02 \\
\hline Dolomitic biomicrite & 0.9 & (4) & 0.8 & 1.4 & 0.02 & (3) & $<0.01$ & 0.03 & & & -- & -- \\
\hline Fossiliferous micrite & 0.8 & (4) & 0.3 & 1.2 & 0.01 & (3) & $<0.01$ & 0.01 & $<0.01$ & (1) & -- & -- \\
\hline Micrite & 0.9 & (5) & 0.6 & 1.1 & $<0.01$ & (3) & $<0.01$ & $<0.01$ & - & & -- & -- \\
\hline Biogenic dolomite & 6.2 & (17) & 0.9 & 31.4 & 7.67 & (13) & $<0.01$ & 68 & 26.2 & (2) & 4.5 & 48.0 \\
\hline Intraclastic dolomite & 7.2 & (14) & 4.8 & 12.6 & 0.17 & (1) & -- & - & -- & & -- & -- \\
\hline Oolitic dolomite & 4.5 & (3) & 4.2 & 4.8 & 0.04 & (3) & $<0.01$ & 0.09 & 0.01 & (1) & -- & -- \\
\hline Pellet dolomite & 20.3 & (7) & 8.8 & 30.2 & 23.2 & (7) & 0.22 & 96 & 26.3 & (7) & 0.34 & 107 \\
\hline Laminated dolomite & 2.7 & (8) & 2.1 & 6.0 & 0.07 & (4) & 0.01 & 0.22 & & & -- & -- \\
\hline $\begin{array}{l}\text { Aphanocrystalline } \\
\text { dolomite }\end{array}$ & 17.9 & (7) & 7.4 & 30.4 & 3.4 & (7) & $<0.01$ & 14 & 3.8 & (5) & $<0.01$ & 10 \\
\hline $\begin{array}{l}\text { Very finely crystalline } \\
\text { dolomite }\end{array}$ & 11.4 & (18) & 2.6 & 17.1 & 0.8 & (15) & 0.01 & 6.9 & 1.8 & (5) & 0.03 & 7.1 \\
\hline Finely crystalline & & & & & & & & & & & & \\
\hline $\begin{array}{l}\text { dolomite } \\
\text { Medium crystalline }\end{array}$ & 10.8 & (68) & 0.3 & 26.4 & 15.3 & (62) & $<0.01$ & 303 & 32.5 & & $<0.01$ & 338 \\
\hline dolomite & 10.9 & $(40)$ & 0.6 & 25.0 & 45.9 & (37) & $<0.01$ & 390 & 134.6 & (5) & 1.3 & 900 \\
\hline Sandstone & 13.1 & (6) & 0.9 & 21.0 & 24.5 & (6) & 0.03 & 119 & 14 & & 0.47 & 42 \\
\hline
\end{tabular}


they are reduced solution-enlarged fractures. Where these fractures are closely spaced, the secondary solution produces vugs; these, too, have been partly reduced by cementation.

\section{INTERPRETATION}

Most investigators who have studied these rocks believe they are collapse breccias resulting from solution of underlying anhydrite (or other evaporite) beds by circulating meteoric waters of low salinity (Nordquist, 1953; Middleton, 1961; Roberts, 1966; McCaleb and Wayhan, 1969; and Sando, 1974). Both Roberts (1966) and Sando (1974) indicated that leaching of the soluble constituents produced large cavities, which undermined the overlying strata causing collapse.

Sando (1974, p. 140) thought that small clasts within Madison Limestone breccias of south-central Wyoming were remnants of thin carbonate beds in the anhydrite. Larger fragments, which he found to increase in size and abundance upward to the breccias zones, were thought to be derived from collapse of roof rock above the large cavities (that is, caves). As noted earlier, there is no systematic upward increase in clast size in the breccia zones studied. Also, the large "clasts" found at the top of the breccia sequence in these wells are in reality blocks of fractured carbonate rather than true collapse breccias; these probably formed in response to settling of the underlying breccias. The author concurs with Stanton's (1966) suggestion that collapse breccias may have formed at the same time as evaporite solution, rather than after a large cavity was produced by complete solution of an underlying evaporite sequence. Such solution, occurring in a near-surface environment (Lucia, 1972), probably caused the uppermost breccia zones in test wells 1,2 , and 3.

Data from this study support the idea of a preAmsden, post-Madison age for the uppermost breccias in test wells 1, 2, and 3. This evidence includes: (1) clasts in the breccias were typically sharply angular, indicating that the carbonates were lithified prior to brecciation; (2) red coloration of the breccia matrix in the uppermost Madison Limestone suggests that weathering and clay infiltration took place prior to deposition of overlying units; (3) textural and compositional similarity of quartzarenite matrix in the uppermost Madison Limestone in well 1 to that of the overlying Amsden indicated that sand infiltration occurred prior to lithification of the Amsden; (4) similarity in clay mineral composition of the uppermost breccia matrix to that of overlying sediments also suggests clay infiltration; and (5) kaolinite in the uppermost breccia in well 1 is probably related to post-Madison, pre-Amsden weathering and soil formation (Roberts, 1966).
Below the uppermost $10 \mathrm{ft}$ or so, most matrix in these breccias consists of carbonate fragments with subordinate quartz silt and clay. This matrix is not ironstained, nor does it contain kaolinite or appreciable amounts of quartz sand. Much of this terrigeneous material may thus represent residual products of the solution process (that is, insoluble residues) rather than material filtered in from above (Sando, 1974). The carbonate matrix is probably finely pulverized carbonate (rock flour of Middleton, 1961), that was subsequently altered by solution and compaction.

In addition to forming breccias, the solution of relatively large volumes of evaporites should have produced ground waters with large $\mathrm{Ca} / \mathrm{Mg}$ (calcium/ magnesium) ratios, which should have been capable of calcitizing nearby pre-existing dolomites. Yet there is little evidence of calcite pseudomorphs after dolomite crystals (that is, dedolomite) in these rocks. In fact, the only occurrences of dedolomite in the Madison Limestone are in two thin sections from near the top of M-3 to M-7 interval in well 1 . There are, however, numerous calcite veins and patches of equigranular calcite within the breccias and adjacent dolomites. Similar veins and patches are found in most Madison Limestone dolomites. The calcite patches are believed to be of replacement origin rather than a cavity-fill because they do not show crystal-enlargement towards their centers (Bathurst, 1971). A replacement origin is also suggested by the occurrence of dolomite inclusions within the calcite. Most often the dolomite is euhedral; rarely does it display corroded margins.

The calcite veins and patches are probably precipitates and replacements that resulted from solution of anhydrite and dolomite; the calcium ion coming from both sources and the carbonate from the dolomite (Hanshaw, Busby, and Lee, 1978). Why there is not more dedolomite in these rocks is unknown; however, one possible explanation is the lack of wide-spread bedded evaporites. The breccias may have been formed by karstic solution of disseminated evaporite nodules which would not have produced large yield $\mathrm{Ca} / \mathrm{Mc}$ ratios required for dedolomitization.

Stable isotope ratios of carbon and oxygen of these secondary calcites indicate that they could have precipitated from present-day ground waters (R. G. Deike, U.S. Geological Survey, 1978, written commun.). Geochemical work by Hanshaw, Busby, and Lee (1978) also indicates that water in the Madison Limestone aquifer is currently dissolving dolomite and sulfates, and precipitating calcite. Whether the replacement calcites are products of ancient or present-day processes is unknown at this time. Perhaps there are several generations of secondary calcites-one related to the solution of anhydrite beds and resultant formation of collapse breccias, and the other related to present-day 
processes. Age dating of a variety of these secondary calcites could resolve the problem.

\section{CHERT}

\section{DESCRIPTION}

Based on external morphology, two major types can be distinguished: nodular chert and bedded chert. Nodular chert occurs in limestones and dolomites throughout the Madison Limestone (plates 1, 2, and 3), whereas bedded chert is restricted to the base of the M-1 and M-3 interval in test well 3. Although chert nodules are widely scattered throughout Madison Limestone carbonates, they tend to be much more abundant in dolomites than limestones. They are usually very light gray to medium gray and vary from less than onehalf in. to about $8 \mathrm{in}$. long. Their shapes are greatly variable. Most, however, have rounded or subrounded exterior margins and are elongated or flattened parallel with bedding. Horizontal permeability values range from less than 0.01 to $129 \mathrm{mD}$. The high permeability value results from intense fracturing. Because of the small number of samples, these values are not considered to be representative. Visible porosity averages about 2 percent and the dominant porosity types are mesomoldic and meso- and small megafracture. Most of the molds have external shapes resembling skeletal allochems or peloids and probably represent constituents that were leached out prior to silicification. A $45-\mathrm{ft}$ thick sequence of bedded chert with subordinate dolomite occurs near the base of the Madison Limestone in well 3 (pl. 3). The chert is generally massive, white to very light gray, and somewhat resembles tripoli, in that it is relatively soft and porous. Finely and very finely crystalline, medium-light-gray dolomite forms about 25 percent of the unit. The dolomite typically occurs as thin, irregularly-shaped stringers and lenses that are crudely parallel with bedding (fig. 6). Most layers are wavy and discontinuous and vary greatly in thickness. Average thickness is about $1 \mathrm{in}$. with a maximum of about 4 in. and minimum of less than one-eighth in. Contacts between the dolomite and lighter-colored chert are very sharp and have a highly irregular corroded appearance. Thin whisps of dolomite commonly project into the adjacent chert, and many of these are bent and distorted. Dolomite also occurs as isolated, irregularlyshaped patches, that in many cases are normal to bedding. Both the chert and dolomite are pervasively fractured. Many of the fractures are open; where they pass through dolomite layers, they commonly show evidence of solution enlargement. An earlier formed set of fractures, which are cut by the open fractures, are filled with coarse anhydrite.

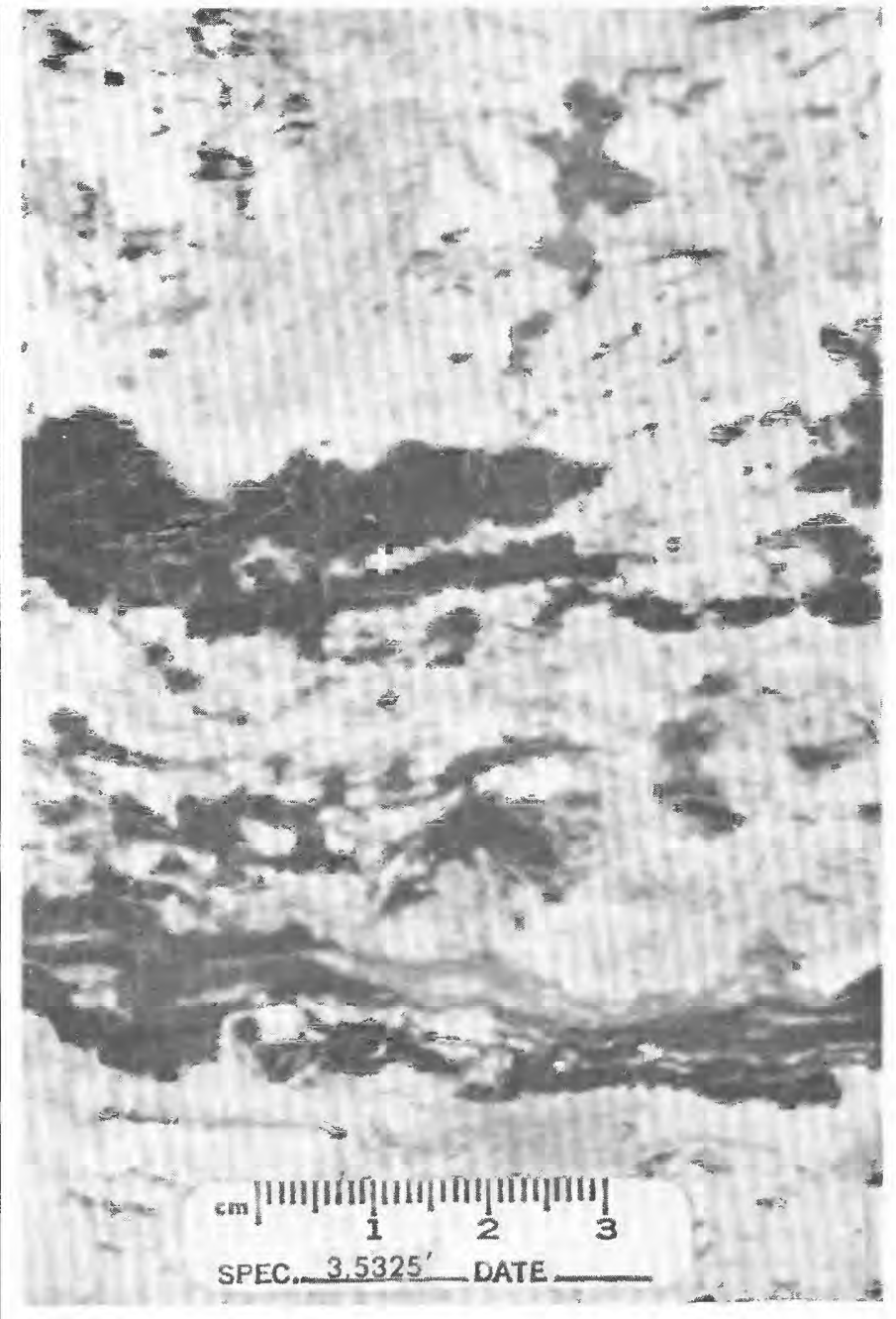

FiguRE 6.-Bedded chert with irregularly shaped stringers and patches of darker dolomite. Base of Madison Limestone interval M-1 to M-3. Test well 3, depth 5,325 ft. Slab. Reflected light.

The bedded chert is texturally similar to the nodular chert and is composed predominantly of anhedral microcrystalline quartz with subordinate megaquartz, chalcedony, and quartzine. Dolomite and anhydrite are also present. Porosity and permeability values for samples of bedded and dolomitic chert are given in table 3. Small megafracture and small mesomolds are the dominant porosity types in both, with subordinate mesointercrystalline chert. The molds probably represent carbonate allochems that were leached out prior to silicification. High porosity and permeability values in the bedded chert result mainly from abundant molds and fractures in the rock.

\section{INTERPRETATION}

Most of the chert nodules were formed by selective replacement of bioclastic limestones or dolomitic bioclastic limestones. A few formed by replacement of 
pellet limestones. Many of the host rocks contained evaporite minerals as evidenced by the presence of relict anhydrite and quartzine. The presence of euhedral dolomite inclusions within the bedded chert suggests that the original rock was dolomitized prior to silicification.

Extensive fractures in the bedded chert may have resulted from regional stresses acting on a relatively brittle rock. It is also possible that fractures developed from dessication of the chert (Wood and Armstrong, 1975).

The source of silica for cherts in the Madison Limestone is not known for certain. What is known, however, is that no widespread volcanic activity supplied glass shards to the area (Craig, 1972). The meager remains of sponge spicules preserved in these cherts may represent only a small percentage of an originally large population, which could have served as a silica source. Although they have not been identified in the Madison Limestone, siliceous radiolarians also lived during the Mississippian, and solution of their skeletons could also have provided silica. One possible source of silica, based on the present-day ground-water flow system, could be precipitation from circulating fresh water. The greatest accumulation of massive silica occurs in test well 3 , in the area where the Lake Basin fault (fig. 7) is acting as an apparent barrier to ground-water flow.

\section{LIMESTONE}

GRAINSTONE

The characteristic features of grainstones are that they are grain-supported and lack a carbonate mud (micrite) matrix. They are cemented by sparry calcite, and, in places, anhydrite, and have low porosity and permeability. Many have been dolomitized; where the proportion of dolomite is large enough, these rocks become dolomites. Dolomitized grainstones may have slightly higher porosity and permeability values than their undolomitized counterparts.

\section{Oosparite}

Description

Oosparites (a variety of grainstone) and dolomitic oosparites occur chiefly in the M-3 to M-7 interval in wells 2 and 3 , and in the following intervals in well 2: M-1 to M-3; M-3 to M-7; M-8.5 to M-12; and M-12 to Mc (pl. 1, 2, and 3). Oolitic dolomites are interbedded with dolomitic oosparites in the M-3 to M-7 interval in well 2, and are believed to represent dolomitized oosparites rather than oomicrites.
Most of the fossil fragments in the rocks are broken and abraded, and many show evidence of rounding. Chert occurs chiefly as a partial replacement of crinoid columnals. Intraclasts, a common accessory, consist primarily of grapestone aggregates and subrounded grains of micrite.

The dominant cement in these rocks is coarse blocky calcite (fig. 8) with subordinate-calcite rim cement on crinoid fragments. In a few samples, thin layers of isopachous-needle cement fringe ooids with the remaining void space filled with blocky calcite spar. Fringing needle cements are characteristic of intertidal or submarine cementation (Scholle, 1978, p. 157), and have previously been reported from Lodgepole Limestone oosparites in the Big Snowy Mountains (Jenks and Wilson, 1972).

Dolomite preferentially replaces not only ooid coatings, but also replaces blocky and rim calcite cement, indicating that dolomitization postdated calcite cementation. Replacement anhydrite commonly engulfs ooids, sparry calcite cement, and dolomite; thus, it must have been the last cement to form.

Mean, minimum, and maximum values of porosity and permeability are listed in table 4 . Values of both are low owing to extensive cementation by calcite, and to a lesser extent, anhydrite. Dolomite oosparities and oolitic dolomites have slightly higher porosity value than oosparities; also, dolomitic oosparites are slightly more permeable than their undolomitized counterparts. In contrast, oolitic dolomites show the lowest average permeability of the three. Most likely, this results from the small number of samples tested. It is also possible, however, that the low permeability of oolitic dolomite could result from very close packing of subhedral and anhedral-dolomite crystals, which would reduce the number and size of pore interconnections.

Interpretation

The presence of well-sorted, cross-bedded oolitic sand mixed with subordinate abraded marine fossils, and the absence of carbonate mud indicate a high-energy, shallow marine-shelf environment (Bathhurst, 1971). Modern ooids form in agitated, warm waters, generally in depths less than $5 \mathrm{~m}$ (Ginsburg and James, 1974).

Initially the oolitic sands probably had porosities in the range of 30 to 35 percent (Dunham, 1962). However, subsequent diagenesis has greatly reduced porosity and permeability. From petrographic evidence, the following generalized sequence of stages of diagenesis can be reconstructed: (1) Micritization of aragonitic ooids by boring algae and fungi on the sea floor; (2) local subsea cementation by aragonitic needle cement; (3) widespread cementation by coarse low-Mg calcite spar, prob- 


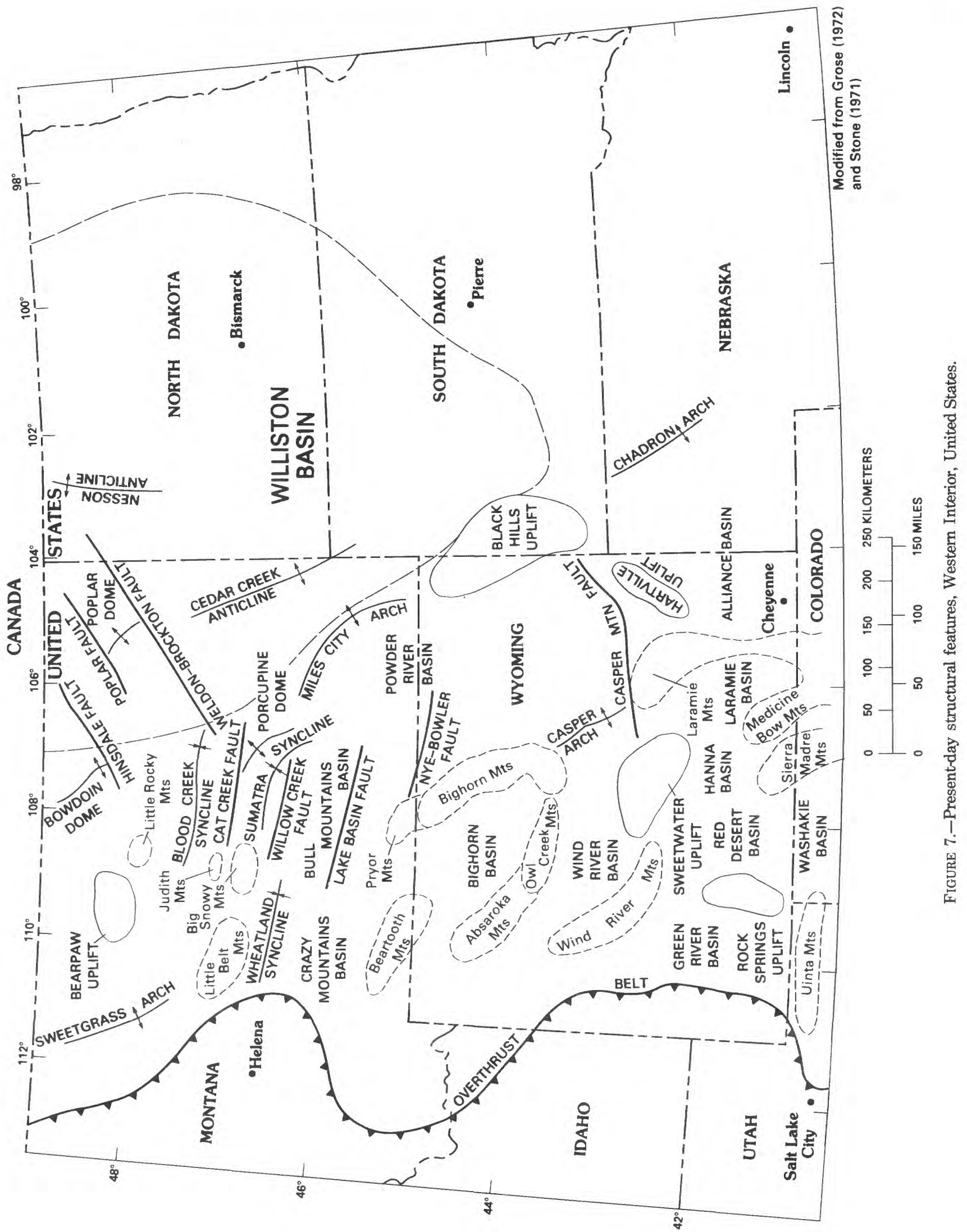




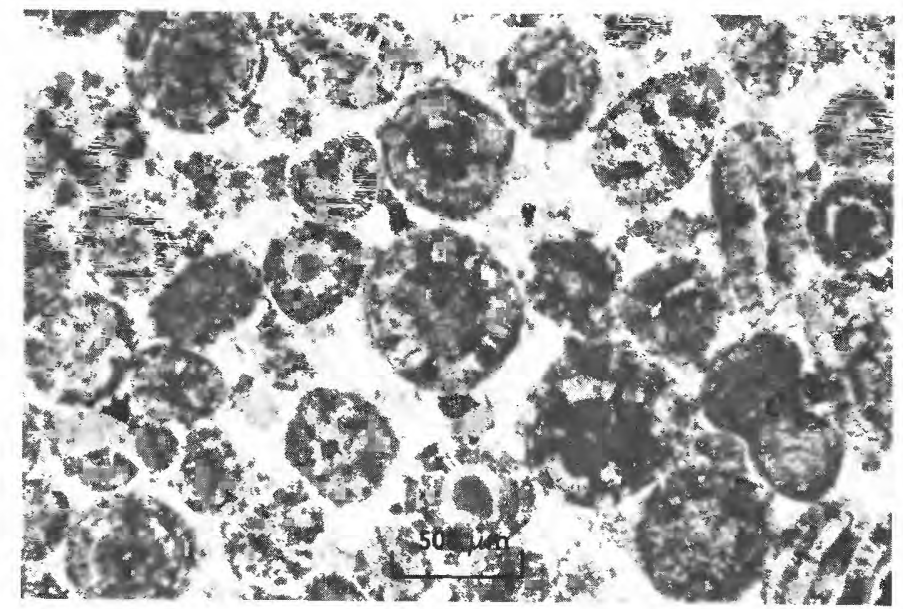

Figure 8.-Medium grained, well sorted oosparite with filled mesointerooid porosity. Ooids display both radial and concentric structure and are cemented by coarse sparry calcite. Elongate ooids have broken brachiopod shells as nuclei. Note compound ooid (c). Porosity is 0.6 percent. Madison Limestone interval M-12 to Mc. Test well 2, depth 6,507.6 ft. Crossed nicols.

ably in the vadose zone; (4) partial or complete dolomitization; and (5) cementation and replacement by anhydrite. In overpacked oolitic grainstones, compaction of ooids preceded stage 3 cementation. It should be pointed out that stages 4 and 5 did not occur in all oosparites; in many instances, state 3 was probably followed by inversion of aragonitic ooids to low-Mg calcite.

\section{PACKSTONE-WACKESTONE}

Because allochemical limestones with micrite matrix show an almost continuous gradation from mudsupported wackestones to grain-supported packstones, no distinction between the two types is made in this study. This group includes biomicrites, biopelmicrites, and pelmicrites, as well as their partly dolomitized counterparts. All are characterized by very low values of porosity and permeability.

\section{Biomicrite}

Description

Biomicrites and dolomitic biomicrites occur chiefly in the $\mathrm{M}-1$ to $\mathrm{M}-3$ and $\mathrm{M}-8.5$ to $\mathrm{M}-12$ intervals in test well 2 (pl. 2). They are also found in the M-3 to M-7 in well 1, and M-12 to Mc intervals in well 2 . Typically, they are interbedded with biopelmicrites, pelmicrites, fossiliferous micrites, and micrites.
Fossils form more than 75 percent of the allochems and consist of echinoderms (dominantly crinoids) and brachiopods with subordinate foraminifers, bryozoans, and small broken shell hash (fig. 9). Ostracodes, pelecypods, and rare solitary corals are sometimes present. Many of the larger crinoid fragments show evidence of abrasion, and brachiopod shells are mostly disarticulated and broken. Some of the bioclasts have micrite envelopes, and, in a few instances, micritized grains occur. Peloids are a widespread accessory; where their percentage is high enough, biomicrites grade into biopelmicrites. The peloids are probably of fecal origin, as evidenced by their elliptical shape and relatively uniform size.

Fine or very finely crystalline dolomite forms less than 3 percent of the rock and occurs as individual euhedral rhombs, which selectively replace mud matrix. Continued dolomitization, that is between 10 and 50 percent dolomite, increases the size and spatial density of the dolomite crystals. During this state, dolomite rhombohedra also start to replace bioclasts, chiefly brachiopods, foraminifers and bryozoans, and come increasingly into contact with each other.

Chert is a common accessory and forms as much as 8 percent of the volume of the dolomitic biomicrites. In biomicrites, it occurs as a replacement or partial replacement of crinoids and brachiopods, whereas in dolomitized biomicrites it occurs chiefly in intercrystalline areas between dolomite rhombs. Subangular quartz silt is ubiquitous. Medium to coarsely crystalline anhydrite is often present as a fracture filling in biomicrite and dolomitic biomicrite; in dolomitic biomicrite it also fills intercrystalline pore spaces.

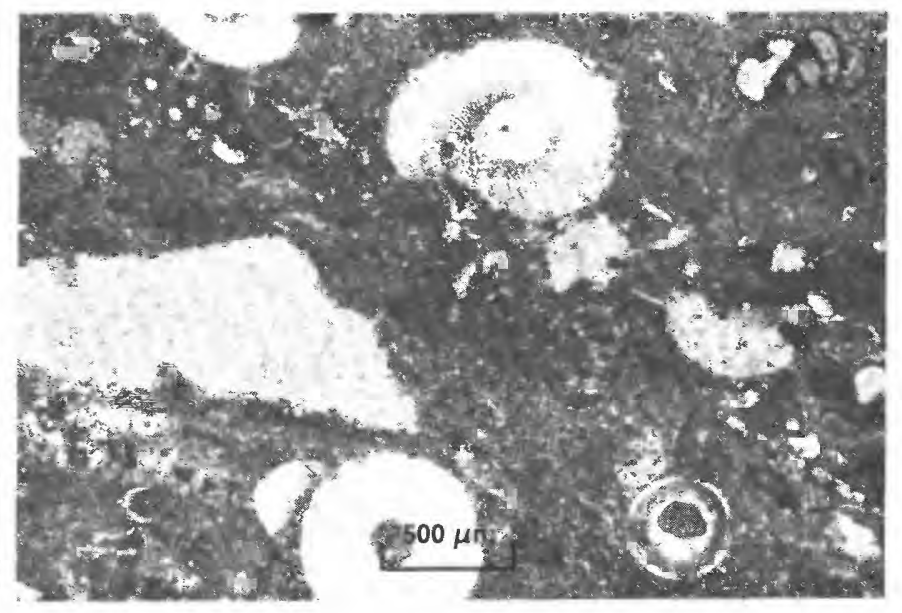

FIGURE 9.-Medium grained, poorly sorted biomicrite (wackestone). Dominant allochems are crinoid fragments with subordinate foraminifers and brachiopods. Micrite fills interparticle pore space. Madison Limestone interval M-12 to Mc. Test well 2, depth 6,533.3 ft. Plane-polarized light. 
The dominant porosity types in both biomicrite and dolomitic biomicrite are micrite-filled mesointerparticle between bioclasts, and microinterparticle between micrite grains. Minor types include cement-filled mesointraparticle, chiefly in bryozoans and foraminifers, and cement-filled mesofracture. Minor intercrystalline porosity also exists in dolomitic biomicrites.

Measured values of porosity and permeability are extremely low in these rocks (table 4). There are several reasons for this: (1) Mesointerparticle pores in micrite are very small owing to compaction and secondary calcite overgrowths (neomorphism); (2) skeletal allochems were dominated by calcitic forms, which did not dissolve to form molds during subsequent diagenesis (Thayer and Textoris, 1977); (3) intraparticle pores within fossil allochems have been filled with calcite spar; and (4) minor fracture pores are filled with anhydrite.

Dolomitic biomicrite has much lower porosity than biomicrite (table 4). This is characteristic of the initial stage of dolomitization (that is, less than 50 percent dolomite), and has been reported previously by a number of investigators (Murray, 1960; Lucia, 1962; Powers, 1962). According to Murray (1960), this porosity decrease results when dolomite crystals are grown from solutions brought in from outside the rock; thus, the nonpourous dolomite crystals occupy space once occupied by micrite, which originally had microinterparticle porosity.

\section{Interpretation}

The biomicrite contains a diverse fauna indicative of open circulation and shallow water. The lack of fine laminations and often pelleted character of the micrite suggest homogenization by burrowing organisms. Worn and disarticulated skeletons indicate that current or wave agitation alternated with quiet water conditions in which micrite could accumulate. This rock type is Wilson's (1975) standard microfacies type 9, which according to him forms at or just below wave base on a shallow shelf. Very early subsea diagenesis by boring algae produced micrite envelopes around some allochems.

Following burial, the sediments were compacted. In a few packstones, syntaxial overgrowths developed on crinoid plates; then, mud filtered in from above prior to compaction. During subsequent fresh water diagenesis, minor aragonite skeletons dissolved to form molds and the $\mathrm{CaCO}_{3}$ (calcium carbonate) reprecipitated nearby, mostly within intraparticle pores of foraminifers and bryozoans. Later, allochthonous cement filled minor molds and infilled remaining intraparticle pore space.
During this later state, aragonitic micrite probably inverted to low-Mg calcite, and, in some cases, the micrite aggraded to microspar or pseudospar. Dolomite crystals selectively replace micrite matrix, and also have been found to replace spar-filled bryozoans and foraminifers, as well as microspar, thus indicating that dolomitization followed cementation.

\section{CARBONATE MUDSTONE}

MICRITE AND FOSSILIFEROUS MICRITE

\section{Description}

Carbonate mudstones containing less than 10 percent grains include micrite and fossiliferous micrite. The two commonly occur together as thin or very thin beds within thicker packstone-wackestone layers; usually the contacts are gradational. They are most abundant in the M-1 to M-3, M-8.5 to M-12, and M-12 to Mc intervals in well 2 (pl. 2). These rocks are mainly medium light gray to medium dark gray. Micrites often display even, parallel laminations, whereas fossiliferous micrites are massive and slightly pelleted.

Except for the difference in fossil content, micrite and fossiliferous micrite are very similar in composition. Echinoderms and brachiopods are the dominant allochems; subordinate bryozoans, foraminifers, and small broken fossil debris also occur. Most show little evidence of abrasion. Chert occurs mainly as a partial replacement of echinoderm plates, and, to a lesser extent, brachiopod shells. In micrites, much of the lime mud has aggraded to microspar, where the proportion is large enough, these rocks grade into microsparites. Dolomite crystals occur chiefly as discrete euhedral rhombs scattered through the rock. The size, distribution, and percent of these dolomite rhombs is directly related to how far the dolomitization process has gone. Secondary anhydrite occurs mainly as a fracture filling.

As is typical of many lithified carbonate mudstones, porosities and permeabilities in these rocks are extremely low (table 4). The main reason for these low values is that mesointerparticle pores in micrite are exceedingly small, owing to compaction and secondary calcite overgrowths on micrite grains (Flügel, Franz, and Ott, 1968). For a comparative example, Flügel, Franz, and Ott (1968) reported that: (1) Bore diameters in Solnhofen micrites average $0.14 \mu \mathrm{m}$ and are small as $0.07 \mu \mathrm{m}$; (2) porosities in these same rocks average less than 3 percent; (3) aggrading neomorphism further reduced pore size; and (4) the little porosity that exists in these rocks is secondary mesofracture and small mesomoldic. 


\section{Interpretation}

The dominance of lime mud indicates a quiet-water environment below wave base. Much of the micrite is laminated which indicates that burrowing organisms were not present. A shallow-shelf environment is envisioned, because the micrites are interbedded with biomicrites of interpreted normal marine origin. Fossiliferous micrites probably accumulated in a very similar setting, but lack of lamination and the pelleted character of the micrite suggest burrowing organisms were present. Fauna in the fossiliferous micrite indicates open marine conditions.

\section{DOLOMITE}

Dolomite is the most abundant rock type in the three wells studied, forming slightly more than two-thirds of the total cored intervals (table 3). If dolomitized limestones are included, this total exceeds 75 percent.

On the basis of inferred origin, dolomite is subdivided into two groups; intertidal-supratidal and replacement. Intertidal-supratidal dolomites include laminated and intraclastic dolomite. Replacement dolomite, the dominant type, includes crystalline dolomite and crystalline dolomite with relict allochems; this later type consists of biogenic, oolitic, and pellet dolomite. Proposed origins for these various dolomite types will be discussed following their descriptions.

INTERTIDAL-SUPRATIDAL DOLOMITE

Laminated Dolomicrite

Laminated dolomicrite is found in a number of intervals, but is most common in the M-3 to M-7 interval in well 1 , the M-8.5 to M-12 interval in well 2 , and in the M-7 to M-8.5 interval in wells 2 and 3 (plates 1,2 , and 3). The dolomicrite is almost always associated with beds of nodular anhydrite, and it commonly occurs with mottled and intraclastic dolomite. Typically, laminated dolomicrite is found directly beneath nodular anhydrite, and often gradationally overlies homogeneous dolomicrite or slightly pelleted dolomicrite. Contact with the overlying anhydrite is generally sharp. Very thin nodular layers of anhydrite commonly occur within the laminated dolomicrite and bend adjacent laminations. Dominant colors are light gray, medium light gray, yellowish gray, and pale yellowish brown.

The characteristic feature of these rocks is their fine lamination, which is usually even and parallel, wavy and parallel, or less commonly, discontinuous, wavy and parallel (fig. 10). In some beds, laminations have been disrupted and broken by mud cracks. Laminations are produced by slight variations in color, which result from compositional and textural differences between adjacent layers. Darker colored layers are always finer grained and appear to be organic rich.

Often, aphanocrystalline dolomite has aggraded to coarser dolomicrospar. Finely to coarsely crysialline anhydrite averages almost 22 percent by volume and occurs mainly as very thin irregularly-shaped lenses and laminae sandwiched between dolomicrite layers. Detrital quartz silt and opaque and clay minerals (predominantly illite) are widespread accessories.

The dominant porosity type ( $>95$ percent) is microintercrystalline with minor small mesofracture and mesomoldic. Porosity values of eight samples average 2.7 percent, and horizontal permeability for four of these samples averages $0.07 \mathrm{mD}$; these low values result from the extremely small size and lack of interconnections of the pores.

\section{Intraclastic Dolomite}

Thin and very thin beds of intraclastic dolomite often occur within laminated dolomite sequences, and are especially common in their uppermost part. Contacts between the two are gradational. Intraclastic dolomite is most abundant in the M-8.5 to M-12 interval in wells 1 and 2, and in the M-7 to M-8.5 interval in wells 2 and 3 (pl. 1, 2, and 3). Its usual colors are yellowish gray, light gray and medium light gray.

Intraclasts are typically slightly darker than surrounding matrix. Intraclasts form nearly 50 percent of

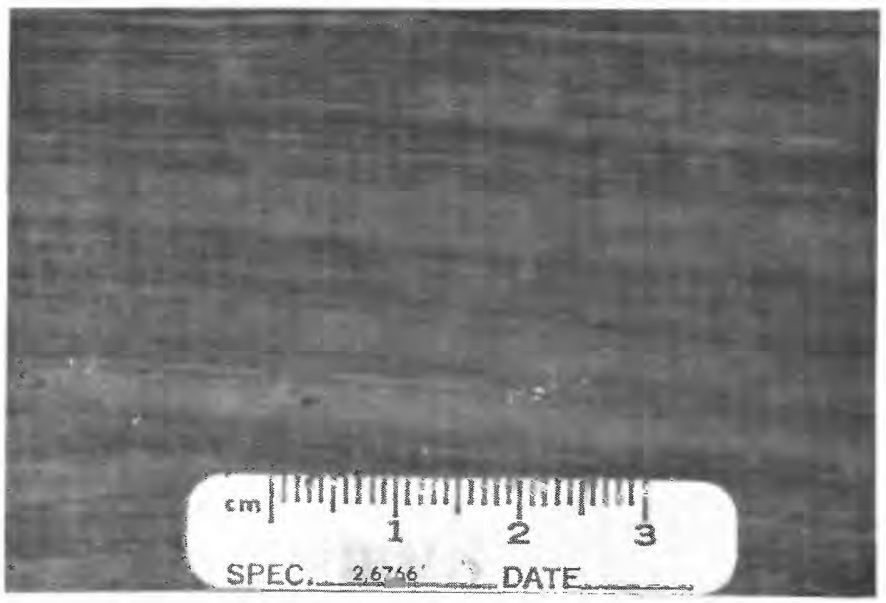

Figure 10.-Thinly laminated dolomicrite of inferred supratidal origin. Porosity is 3.3 percent, and horizontal permeability is $0.22 \mathrm{mD}$. Near top of Madison Limestone interval M-7 to M-8.5. Test well 2, depth 6,677 ft. Slab. Reflected light. 
the rock, and range in size from several millimeters to several centimeters long. Most are elongate pieces of laminated dolomicrite with angular or subangular edges; minor massive dolomicrite intraclasts also occur. Most are parallel or subparallel with bed boundaries and occur as thin discontinuous layers across the core. The dolomicrite matrix consists of anhedral dolomite crystals that average less than 8 mean diameters $(\phi)$ or 4 micrometers $(\mu \mathrm{m})$. The matrix is commonly brecciated and pelleted, and contains numerous elongate fenestral pores ("bird's-eye" structures) that are partially reduced by coarser grained dolomite, anhydrite, or sparry calcite.

Measured values of porosity in these rocks are high, owing to numerous open fenestral pores. The mean value for four samples is 7.2 percent, with a range from 4.8 to 12.8 percent. Only one horizontal permeability measurement was made; its value is $0.17 \mathrm{mD}$.

\section{CRYSTALLINE DOLOMITE WITH RELICT ALLOCHEMS}

Biogenic Dolomite

Biogenic dolomite generally occurs as massive, thin to thick beds in (1) M-1 to M-3 interval in wells 2 and 3; (2) M-3 to M-7 interval in wells 1 and 3; and (3) M-8.5 to M-12 interval in wells 2 and 3 (pl. 1, 2, and 3). It is commonly associated with dolomite biomicrite and dolomitic biopelmicrite into which it grades. Colors are dominantly medium light gray, medium gray, light olive gray and greenish gray.

Relicts of fossil allochems are chiefly echinoderms (fig. 11) with subordinate brachiopods and bryozoans. As dolomitization proceeds towards completion, echinoderm fragments usually remain as the last vestiges of the former rock. If total dolomitization occurs, many of the echinoderms disappear. Echinoderms are usually recognizable as coarse single crystals of calcite (fig. 11) or dolomite, or as blebs of chert that have external shapes reminiscent of crinoid fragments. Patches of micrite or peloids sometimes remain where the rock contains less than 70 percent dolomite. Detrital quartz silt, authigenic illite, and opaque minerals are common accessories.

Measured values of porosity and permeability are given in table 4. Porosity averages 6.2 percent and horizontal permeability $7.7 \mathrm{mD}$. Mean (arithmetic) permeability is greatly affected by several high values, which are as great as $68 \mathrm{mD}$. Because permeability follows a log-normal distribution, a more realistic average can be obtained by computing the geometric mean (Thayer and Textoris, 1977), which is $0.1 \mathrm{mD}$.

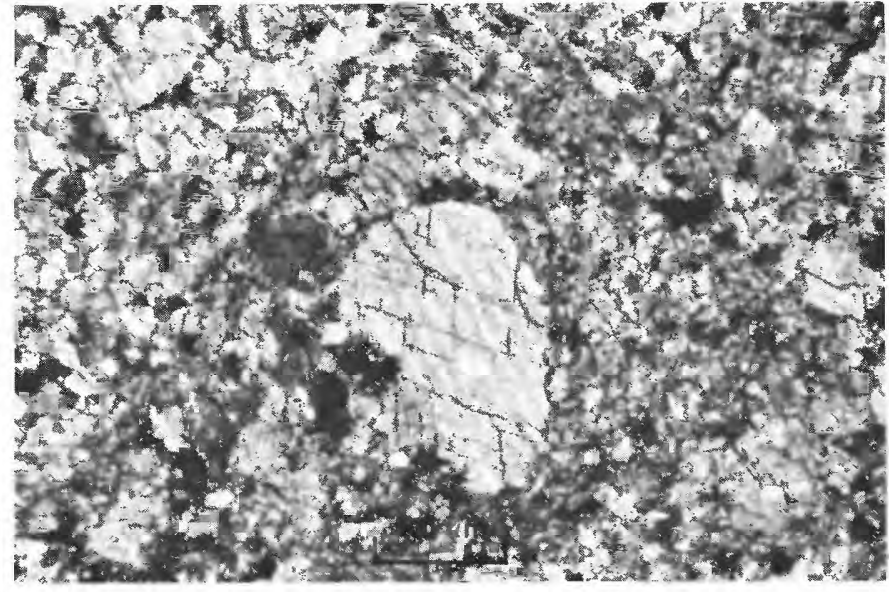

Figure 11.-Medium crystalline biogenic dolomite. The large grain of calcite in the center is probably a replacement of a crinoid fragment. Fabric of the dolomite is hypidiotopic equigranular. Porosity, mainly intercrystalline, is 10.4 percent, and permeability is $0.48 \mathrm{mD}$. Base of Madison Limestone interval M-1 to M-3. Test well $3,5,336.1 \mathrm{ft}$. Crossed nicols.

\section{CRYSTALLINE DOLOMITE WITHOUT} RELICT ALLOCHEMS

Crystalline dolomite is the predominant Madison Limestone rock type, forming about 60 percent of the total cored intervals. It is also the dominant rock type in the uppermost Devonian in all three wells (pl. 1, 2, and 3). In the cored Madison Limestone intervals, it is found within all marker beds, and typically forms greater than 50 percent of individual units. It is least abundant in the M-7 to M-8.5, M-8.5 to M-12, and M-12 to Mc intervals of well 2 (p. 2).

Most crystalline dolomites are thickly and very thickly bedded, and the contacts with adjacent units are commonly gradational. Typically, they are massive and totally devoid of primary sedimentary structures. Faint traces of relict bedding and textural mottling are rarely seen. As noted previously, small chert nodules are relatively common in these rocks.

Crystalline dolomites are subdivided on the basis of grain size into aphanocrystalline, very finely crystalline, finely crystalline, and medium crystalline types. Coarsely crystalline dolomite occurs only in the uppermost Devonian in well 1 . Finely and medium crystalline dolomites form slightly greater than 80 percent of the total. Very little compositional difference exists between these dolomite types. Variations in the total percentage of dolomite (dolomite and dolomicrite) reflect differences in the proportions of visible voids. That is, the percentage of visible voids increases with increasing grain size, causing a concomitant drop in the total dolomite percentage. 
The dolomites display a variety of porosity types, and, in most cases, a single sample has compound porosity consisting of two or more types. Dominant porosity types are intercrystalline (fig. 12) and moldic (fig. 13). Intercrystalline pores are generally small mesoor microsize; whereas, moldic is dominantly mesosize. In numerous places, intercrystalline pores have been reduced or filled by secondary chert, calcite, or anhydrite. Calcite and anhydrite also reduce or fill moldic pores. In rare instances anhydrite (gypsum?) crystals have been subsequently leached from the rock to form crystal molds.

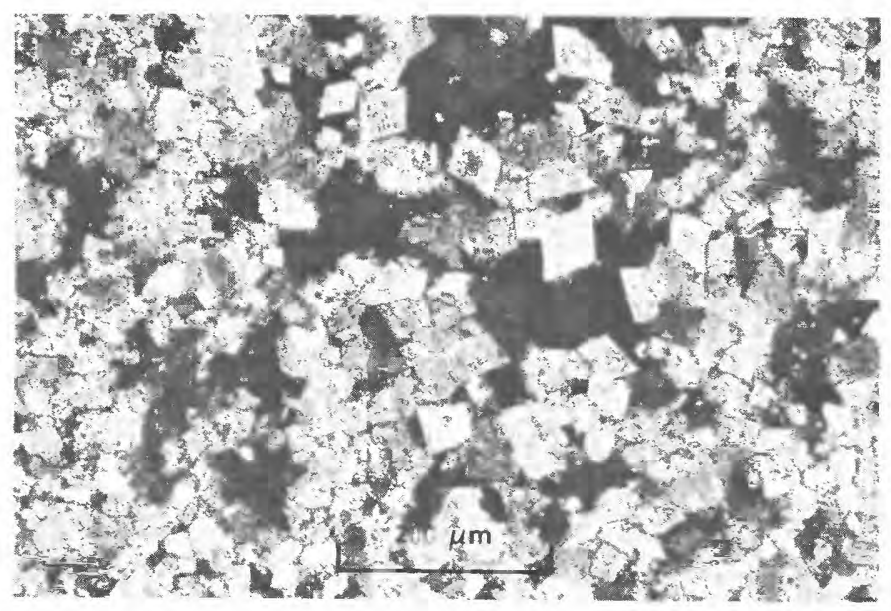

Figure 12.-Intercrystalline porosity in finely crystalline dolomite. Porosity is 18.4 percent and horizontal permeability is $21 \mathrm{mD}$. Madison Limestone interval M-3 to M-7. Test well 1, depth 2,811.6 ft. Crossed nicols.

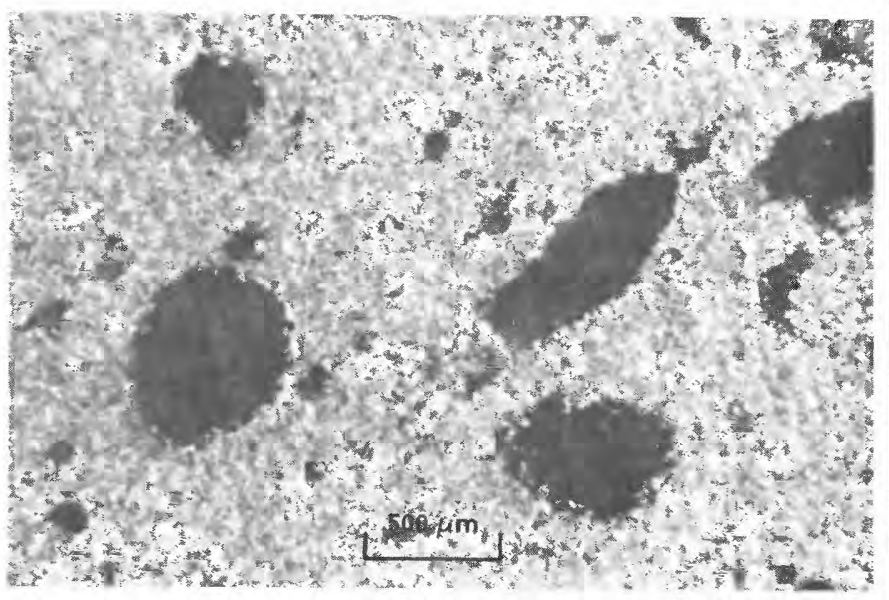

Figure 13.-Moldic porosity in finely crystalline replacement dolomite with xenotopic fabric. The molds range from micro-tolarge mesosize. The size and shape of the larger molds suggest that they were crinoid fragments that have been leached out. Porosity is 4.8 percent and horizontal permeability is $9.9 \mathrm{mD}$. Madison Limestone interval M-3 to M-7. Test well 3 , depth $4,391.5 \mathrm{ft}$. Crossed nicols.
The wide range of porosity and permeability values for these rocks is given in table 4. Aphanocrystalline dolomite has the highest average porosity, whereas the other types have similar values. The high average porosity results mainly from the small number, and the fact that several very high values bias the statistic. Generally average permeability values show an increase with increasing grain size (table 4). As noted before, extreme permeability values greatly bias the arithmetic mean; a more realistic picture of the distribution can be obtained from the geometric mean. Its values for horizontal permeability are: Aphanocrystalline dolomite, $0.28 \mathrm{mD}$; very finely crystalline dolomite, $0.29 \mathrm{mD}$; finely crystalline dolomite, $0.64 \mathrm{mD}$; and medium crystalline dolomite, $4.24 \mathrm{mD}$. Thus, even though these values are lower than corresponding arithmetic means, they still show an increase with increasing dolomite crystal size.

\section{Interpretation}

Fine-grained dolomites interpreted as having formed in peritidal environments include laminated dolomicrite, mottled dolomicrite, and intraclastic dolomite. Some of the crystalline pellet dolomites also formed in these environments. The origin is inferred on the basis of their sedimentary characteristics and relations with adjoining deposits (that is, vertical sequence). Comparison of these features with those reported from several known modern and ancient environments suggests deposition in a peritidal complex somewhat similar to the arid, seamarginal sabkas of the Persian Gulf (Kinsman, 1969; Purser and Evans, 1973; Shearman, 1978; and Kendall, 1979).

An idealized diagram shows the Madison Limestone shallowing-upward (regressive) peritidal sequence (fig. 14). The diagram is a composite based on a number of individual sequences (cycles) in the three test wells, and includes superimposed early diagenetic sabkha evaporites. These sequences are often stacked directly on top of each other, and frequently recur interspersed with shallow-shelf carbonates. The cyclic recurrence of these transgressive-regressive sequences reflects numerous changes in sea level. The numerous fluctuations of sea level imply that wedges of intruded seawater and meteoric water must have flushed through the carbonate sediments numerous times, which led to widespread dolomitization and diagenetic changes.

Many of the crystalline dolomites that are not stratigraphically associated with the sabkha dolomites may have formed by some form of meteoric water-sea water mixing process in the subsurface shoreline environment (Hanshaw, Back, and Deike, 1971; Folk and Land, 1975; 


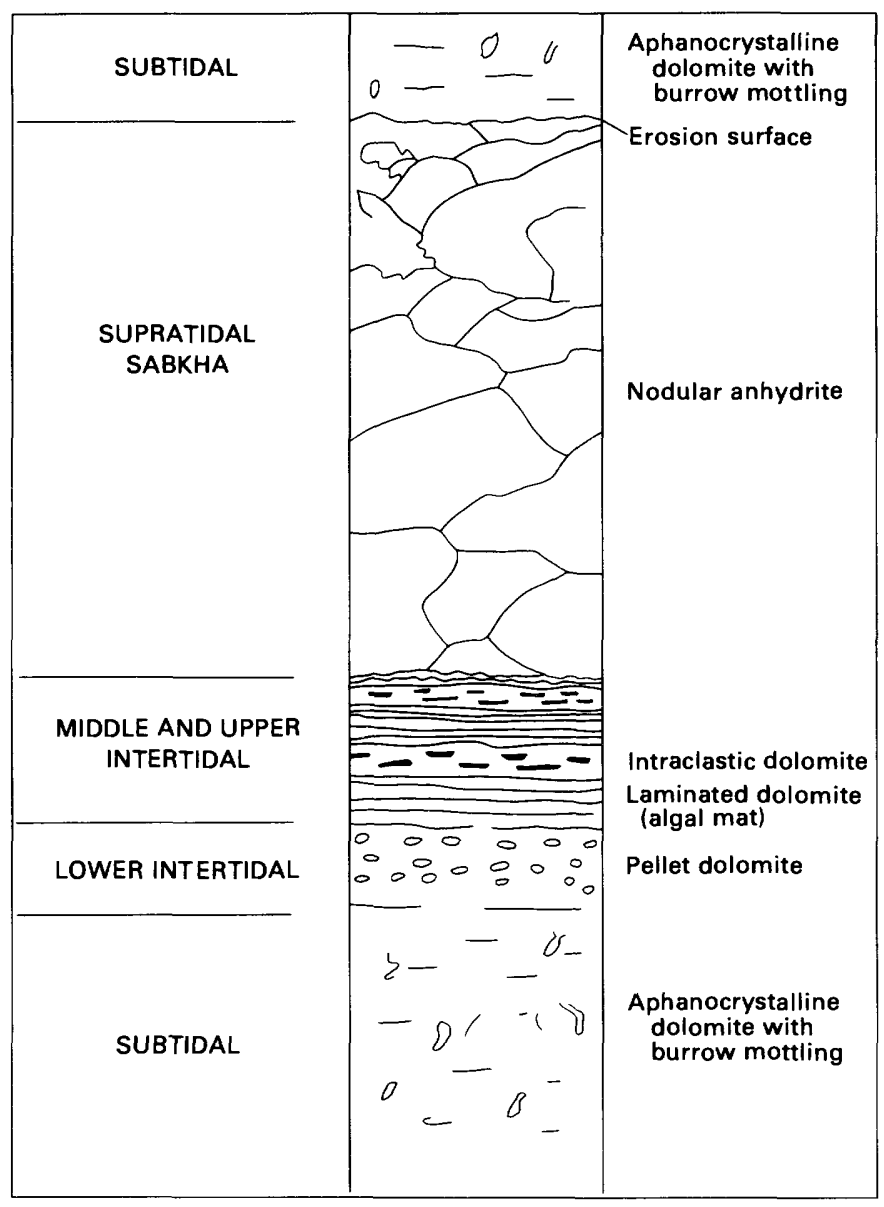

Figure 14.-Idealized Madison Limestone shallowing-upward (regressive) peritidal sequence.

and Land, Salem, and Morrow, 1975). Evidence favoring such a process includes relative coarseness of the crystalline dolomites and their replacement origin, which, in most instances, postdates early limestone diagenesis. Replacement dolomites containing abundant anhydrite do not fit this category and probably represent totally recrystallized sabkha dolomites. Whether recrystallization occurred below a younger sabkha surface by reflux, or in a subsurface shoreline environment by a meteoric water-sea water mixing process, is unknown. Work in progress by Ruth G. Deike (U.S. Geological Survey) on the geochemistry of Madison Limestone dolomites should help resolve this problem and provide additional information on origin(s) of these various types.

Crystalline replacement dolomites without allochem ghosts could have been produced by dolomitization of any type of preexisting limestone or carbonate sediment. However, the strong fabric selectivity shown by dolomite to replace micrite matrix in associated dolomitic limestones, which underwent early diagenetic alternation prior to dolomitization, indicates that most of the crystalline dolomites replaced micrite-rich limestones rather than their unlithified equivalents. This fabric selectivity which has been noted in a number of areas (Murray, 1960; Lucia, 1962; and Murray and Lucia, 1967) and results from composition of the micrite, its initially higher microporosity and permeability, and the large surface area of micrite relative to volume (Davies, 1979).

Using this line of reasoning, most biogenic dolomites are believed to be former biomicrites. Many of the crystalline dolomites contain numerous molds that have the size and shape of crinoids; these, too, are interpreted as dolomitized biomicrites. However, not all crystalline dolomites are replacements of mud-rich limestones, as demonstrated by the presence of dolomitized grainstones, such as dolomitic biosparite and oosparite.

The origin of intercrystalline porosity (sucrose) in dolomites has been described in detail by Murray (1960). Dolomite occupies about 13 percent less molar volume than calcite (Weyl, 1960). However, most dolomite replacement is volume for volume and uses extra $\mathrm{CO}_{3}$ (carbonate) ions, as the $\mathrm{Ca}$ is replaced by $\mathrm{Mg}$. If carbonate required for dolomite rhomb growth comes from dissolution of carbonate within the system (local source), there will be a net increase in porosity equal to the sum of the original rock porosity plus the molar volume difference of 13 percent (Murray, 1960). Rhomb growth will continue, using unreplaced calcium carbonate until a porous framework of rhombs results. The final result of this process will be sucrose dolomite with well-developed intercrystalline porosity. Intercrystalline porosity can also be produced by partial dolomitization of a limestone with subsequent dissolution of the relict calcite. In this instance, the carbonate necessary for dolomite growth is derived from outside the system (distant source). The second process in unlikely, because no evidence exists for calcite dissolution in the Madison Limestone.

\section{DESCRIPTION OF CORES FROM TEST WELLS}

The cored intervals of the three test wells represent most of the typical rock types and depositional environments of the Madison Limestone. Exact locations of the wells and detailed lithologic descriptions of the cored intervals with each are given in Blankennagel, Miller, Brown, and Cushing (1977) for well 1, Brown, Blankennagel, Busby, and Lee (1977) for well 2, and Blankennagel, Howells, Miller, and Hansen (1979) for well 3. 
Detailed graphic logs summarizing the petrology, porosity, permeability, and depositional environments of the cored Madison Limestone intervals are shown for well 1 (pl. 1), well 2 (pl. 2), and well 3 (pl. 3). Cored intervals from parts of adjacent stratigraphic units are also included. At the scale at which these are drawn, beds as thin as 2 feet are shown on the lithologic columns. Subdivision within this column are based on dominant lithologic characters; some of the subdivisions are arbitrary because of mixing of rock types. The curves showing inferred environments of deposition are based on information from sedimentary structures, rock type, and vertical sequence.

Chaotic mixing of clasts within breccia intervals makes it impossible to decipher preexisting depositional environments on the basis of clast type. Further, because the amount of vertical settling of these clasts is unknown, their original stratigraphic position cannot be determined. Petrographic data for samples within breccia intervals represent bulk compositions of these rocks. For example, if a rock consisted of 80 percent micrite clasts and 20 percent sparry calcite cement, its composition would be shown as 80 percent micrite and 20 percent spar. Possible confusion can be avoided by relating rock types in the lithologic column directly with the columns showing compositional data.

Curves showing various porosity types are expressed as percentages of total visible porosity, which is shown as a separate column, labeled voids. Logarithmic scales are used where values show extremes, such as those for permeability, percent insoluble residue, and percent quartz. The percentage scales for compositional data are not necessarily the same on each plate. Curves showing bulk X-ray data are usually in good agreement with those derived from point.count data. Major differences between the two arise from slight differences in sampling position or sample inhomogeneity.

Examination of the curves allows ready comparison of porosity and permeability values with rock type, grain size, porosity type, petrographic composition, and bulk composition. Such examination reveals that in test wells 1,2 , and 3 , high values of porosity and permeability are typically associated with large percentages of fine and medium crystalline dolomite, which have low anhydrite and spar content, and large percentages of visible voids and intercrystal and moldic pores. Percentages of visible voids provide insight into pore sizes because only larger ones can be seen with a polarizing microscope. Thus where pores are microsize, percentage of voids will be small, conversely, large percentages of visible voids indicate large numbers of meso- and megasize pores.

The percentages of major rock types in the cored Madison Limestone intervals in each of the three wells is summarized in table 5. On the average, intervals in test well 2 contain less dolomite than those in wells 1 and 3 . Also, wells 2 and 3 contain considerable amounts of anhydrite, which is lacking in well 1. The large percentage of chert in the M-1 and M-3 interval of well 3 results from the thick layers of chert and dolomitic chert discussed previously.

Average values of porosity and permeability of marker units in each well are given in Table 6 . Highest values of both are attained in the M-7 to M-8.5 interval of well 1 , where the percentage of finely and medium crystalline dolomite is highest and little or no anhydrite is present to clog pores. Comparison of tables 5 and 6 shows that low values of porosity and permeability in these intervals are associated with large percentages of limestone; high values of both porosity and permeability generally occur where dolomite percentage is large. However, large dolomite content does not necessarily mean high porosity and permeability, as shown by the M-7 to M-8.5 interval in well 3 . Here, anhydrite content is great enough to significantly reduce porosity and permeability (table 5). Open fractures also affect porosity and permeability, as demonstrated by the M-8.5 to Mc interval of well 3. Relatively high permeability values in this interval result mainly from the high percentage of fracture porosity (pl. 3), which has not been reduced or filled. Generally, fracture porosity is best developed in well 3 and is related to postconsolidation tectonic activity. A number of other factors greatly influence porosty and permeability in dolomites; these will be discussed in the following section.

\section{POROSITY AND PERMEABILITY RELATIONS}

Porosity and permeability values of all Madison Limestone samples were plotted as cumulative curves using normal and log-normal probability scales, respectively. Porosity shows a normal distribution, although the ends of the curve do not fit perfectly (fig. 15). Horizontal permeability shows a log-normal distribution, with a significant break in slope at about the 10 $\mathrm{mD}$ value (fig. 16). Similar distributions have been reported from a number of other carbonate units (Davis, 1969; Thayer and Textoris, 1977). Mean porosity for the Madison Limestone is 8.4 percent, and mean (arithmetic) permeability is $15.8 \mathrm{md}$. Both porosity and permeability have very large standard deviations, 7 percent and $53 \mathrm{mD}$, respectively, which are common in most carbonate units (Thayer and Textoris, 1977). Because the Madison Limestone is relatively heterogeneous, permeability shows extreme values; thus, the geometric mean is probably more representative of 
TABLE 5.-Percentage of major rock types in cores of Madison Limestone marker intervals in U.S. Geological Survey test wells 1, 2, and 3

\begin{tabular}{|c|c|c|c|c|c|}
\hline \multirow{3}{*}{ Test well marker intervals } & \multicolumn{5}{|c|}{ Rock Types } \\
\hline & \multicolumn{3}{|c|}{ Carbonate } & \multirow[b]{2}{*}{ Dolomite } & \multirow[b]{2}{*}{ Limestone' } \\
\hline & Anhydrite & breccia & Chert & & \\
\hline & \multicolumn{5}{|c|}{ Test well 1} \\
\hline 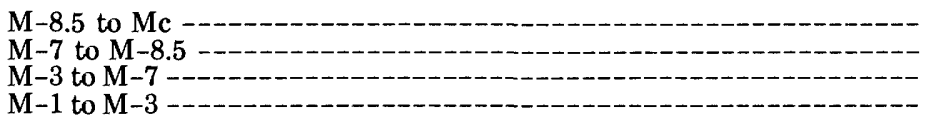 & $\begin{array}{l}- \\
- \\
-\end{array}$ & $\begin{array}{r}23 \\
5 \\
3 \\
-\end{array}$ & $\begin{array}{c}1 \\
- \\
1 \\
1\end{array}$ & $\begin{array}{l}63 \\
95 \\
74 \\
90\end{array}$ & $\begin{array}{r}13 \\
- \\
22 \\
9\end{array}$ \\
\hline $\mathrm{M}-1$ to $\mathrm{M}-3$ & \multicolumn{5}{|c|}{ Test well 2} \\
\hline \multirow[t]{2}{*}{$\begin{array}{l}\mathrm{M}-12 \text { to } \mathrm{Mc}-\mathrm{M} \\
\mathrm{M}-8.5 \text { to } \mathrm{M}-12-1 \\
\mathrm{M}-7 \text { to } \mathrm{M}-8.5-3 \text { to } \mathrm{M}-7- \\
\mathrm{M}-1 \text { to } \mathrm{M}-3-\end{array}$} & $\begin{array}{r}- \\
81 \\
10 \\
2\end{array}$ & $\begin{array}{l}53 \\
7 \\
- \\
- \\
-\end{array}$ & $\begin{array}{c}- \\
1 \\
1 \\
- \\
1\end{array}$ & $\begin{array}{l}11 \\
45 \\
66 \\
61 \\
54\end{array}$ & $\begin{array}{r}36 \\
39 \\
2 \\
29 \\
43\end{array}$ \\
\hline & \multicolumn{5}{|c|}{ Test uell 3} \\
\hline 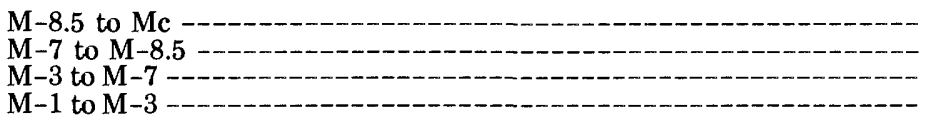 & $\begin{array}{r}2 \\
10 \\
1 \\
2\end{array}$ & $\begin{array}{l}5 \\
- \\
-\end{array}$ & $\begin{array}{c}- \\
\overline{29}\end{array}$ & $\begin{array}{l}89 \\
88 \\
36 \\
69\end{array}$ & $\begin{array}{r}4 \\
2 \\
63 \\
1\end{array}$ \\
\hline
\end{tabular}

TABLE 6.-Porosity and permeability of cores in Madison Limestone marker intervals in U.S. Geological Survey test wells 1, 2, and 3 [Numbers in parentheses $(\mathrm{n})$ behind numbers indicate number of samples tested]

\begin{tabular}{|c|c|c|c|c|}
\hline \multirow{2}{*}{ Test well marker intervals } & \multirow{2}{*}{$\begin{array}{l}\text { Average } \\
\text { porosity } \\
\text { percent }\end{array}$} & \multicolumn{3}{|c|}{$\begin{array}{l}\text { Horizontal permeability } \\
\text { (mD) }\end{array}$} \\
\hline & & \multicolumn{2}{|c|}{$\begin{array}{l}\text { Arithmetic } \\
\text { mean }\end{array}$} & $\begin{array}{l}\text { Geometric } \\
\text { mean }\end{array}$ \\
\hline & \multicolumn{4}{|c|}{ Test well 1} \\
\hline \multirow[t]{2}{*}{$\begin{array}{l}M-8.5 \text { to } M c \\
M-7 \text { to } M-8.5 \\
M-3 \text { to } M-7- \\
M-1 \text { to } M-3-\end{array}$} & $\begin{aligned} 7.6 & (20) \\
16.9 & (18) \\
14.2 & (19) \\
16.7 & (9)\end{aligned}$ & $\begin{array}{r}0.3 \\
76.3 \\
27.2 \\
60.9\end{array}$ & $\begin{array}{l}(21) \\
(19) \\
(22) \\
(9)\end{array}$ & $\begin{array}{l}0.01 \\
5.9 \\
0.6 \\
1.7\end{array}$ \\
\hline & \multicolumn{4}{|c|}{ Test well 2} \\
\hline \multirow[t]{2}{*}{$\begin{array}{l}\text { M-12 to Mc- } \\
\text { M-8.5 to M-12- } \\
\text { M-7 to M-8.5- } \\
\text { M-3 to M-7- } \\
M-1 \text { to M-3- }\end{array}$} & $\begin{array}{ll}5.5 & (9) \\
6.2 & (41) \\
1.8 & (14) \\
7.6 & (24) \\
4.0 & (35)\end{array}$ & $\begin{array}{l}0.02 \\
0.6 \\
0.05 \\
2.9 \\
0.03\end{array}$ & $\begin{array}{l}(4) \\
(28) \\
(5) \\
(17) \\
(17)\end{array}$ & $\begin{array}{l}0.01 \\
0.03 \\
0.02 \\
0.13 \\
0.02\end{array}$ \\
\hline & \multicolumn{4}{|c|}{ Test well 2} \\
\hline $\begin{array}{l}\mathrm{M}-8.5 \text { to } M c- \\
M-7 \text { to } M-8.5- \\
M-3 \text { to } M-7- \\
M-1 \text { to } M-3-\end{array}$ & $\begin{aligned} 9.1 & (22) \\
7.4 & (23) \\
9.2 & (8) \\
15.3 & (12)\end{aligned}$ & $\begin{array}{r}16.2 \\
1.2 \\
17.8 \\
7.9\end{array}$ & $\begin{array}{l}(22) \\
(23) \\
(8) \\
(12)\end{array}$ & $\begin{array}{l}5.0 \\
0.4 \\
1.1 \\
2.0\end{array}$ \\
\hline
\end{tabular}

"average" permeability (Davis, 1969). Its value is 0.25 $\mathrm{mD}$, which is nearly identical to that of the median, which is $0.30 \mathrm{mD}$ (fig. 16). The median value of porosity is 6.3 percent, which corresponds closely with the mean.

Samples used to construct the cumulative curves were selected randomly; thus, the curves are considered to be representative of the Madison Limestone in the area of greatest interest (fig. 1) and can be used as predictive tools. For example, examination of the cumulative curve for porosity (fig. 15) reveals that only 5 percent of the Madison Limestone population will have porosity values greater than about 20 percent. Likewise, examination of figure 16 shows that only 5 percent of the total population is likely to have horizontal permeabilities greater than $35 \mathrm{mD}$.

Limestones of the Madison Limestone are characterized by low values of porosity and permeability (fig. 17), with grainstones showing slightly higher values than other types. As pointed out before, the main reason for these low values is that the limestones underwent early diagenetic cementation, which, in most instances, filled interparticle pore spaces. 


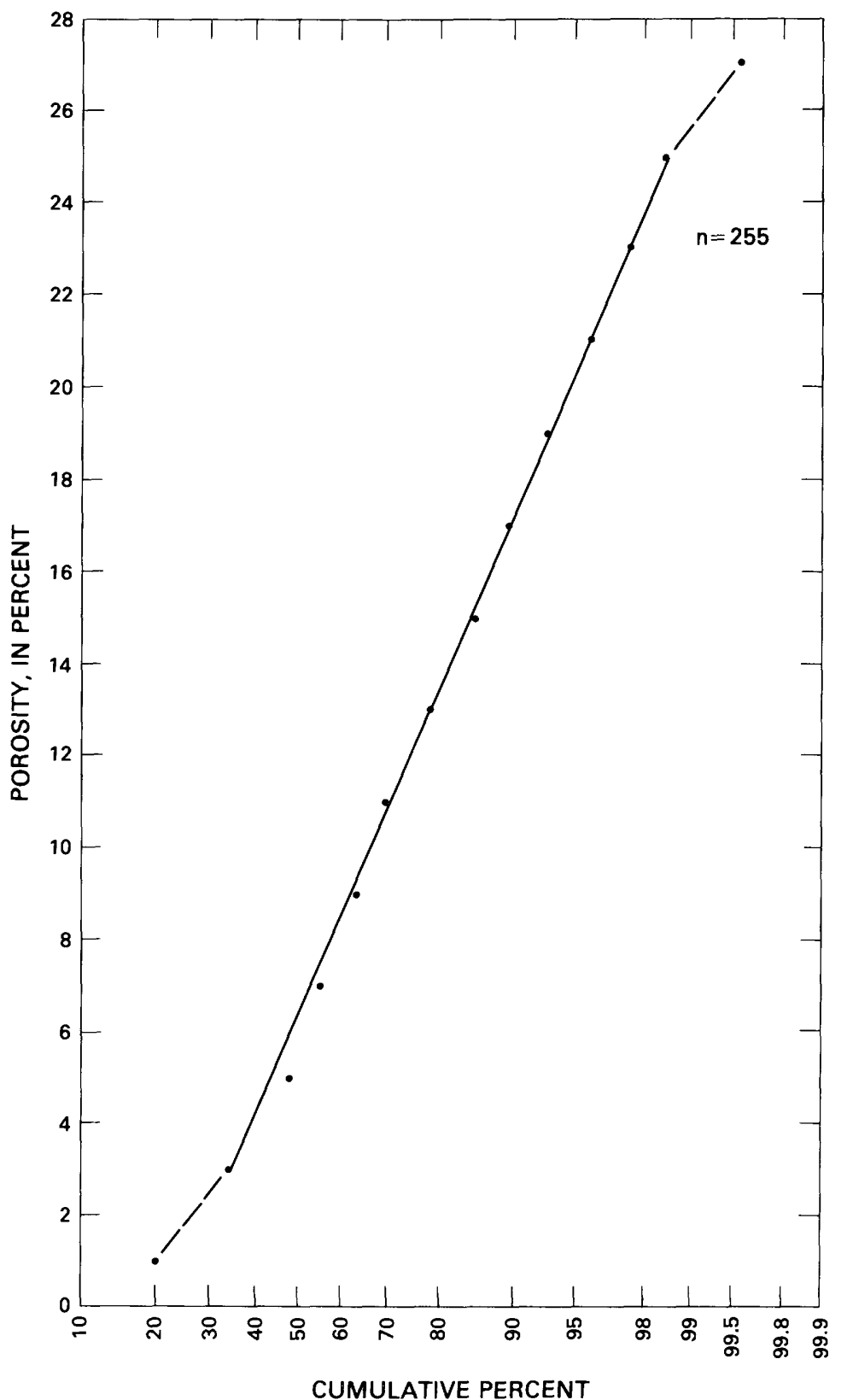

FIGURE 15.-Cumulative curve of porosity of all Madison Limestone samples. Porosity is plotted on a normal probability scale.

In contrast, crystalline dolomites have the highest porosities and permeabilities in the three Madison Limestone test wells, even though they show considerable range (figs. 18 and 19). Although not significant at the 95 percent confidence level, there is a crude positive correlation between porosity and horizontal permeability as well as between porosity and vertical permeability. Generally, medium crystalline dolomites have highest values of porosity and permeability, closely followed by finely crystalline dolomites (figs. 18 and
19). Outliers that have low porosity and moderately high permeability values represent samples with fracture porosity, whereas samples that have high porosity and low permeability either have extremely small pores or moldic and vug porosity in which the pores are not connected.

Plots of dolomite mean size and standard deviation (sorting) against porosity (figs. 20 and 21 ) show complete scatter, indicating that these parameters do not control porosity by themselves. If all or most of the 


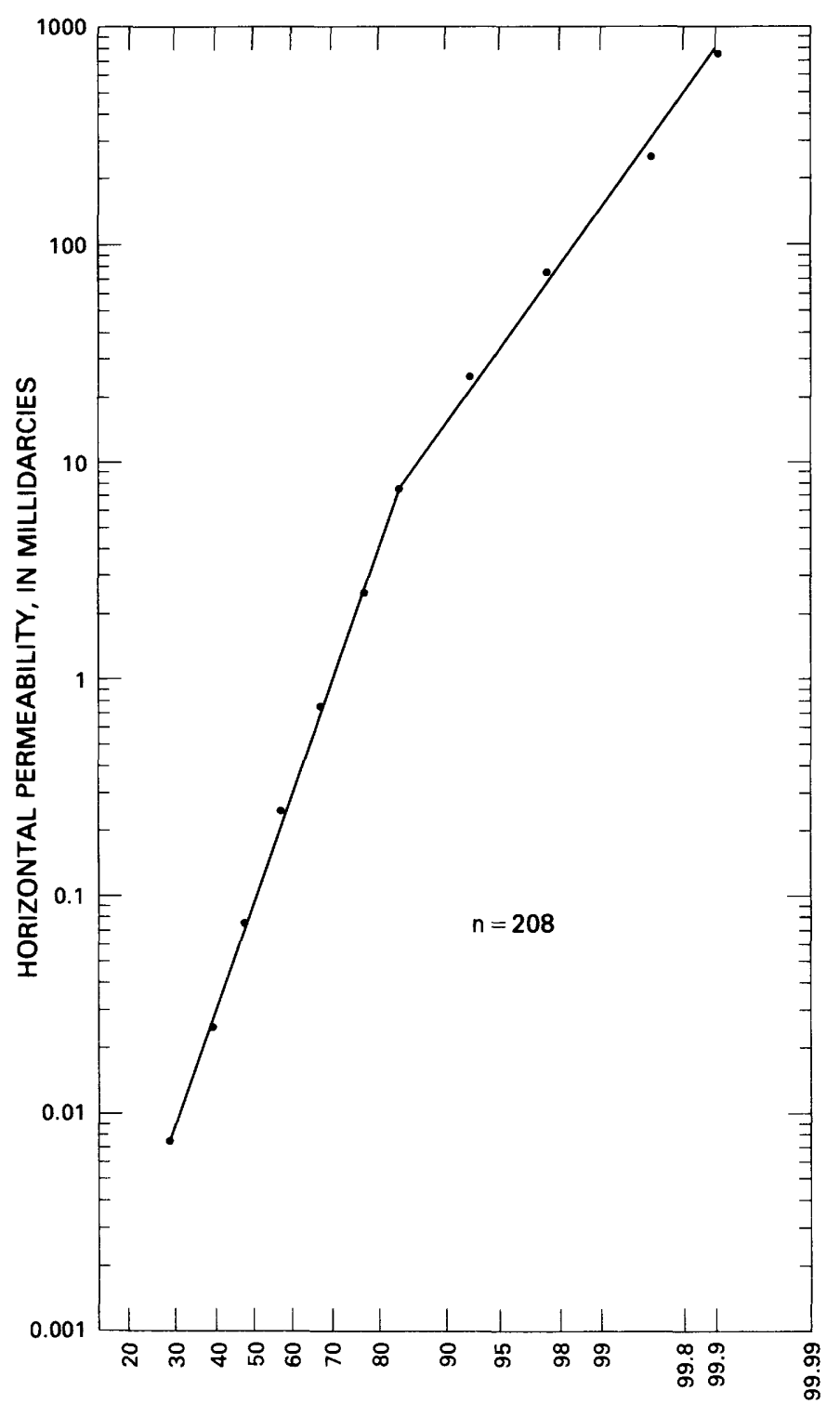

CUMULATIVE PERCENT

FIGURE 16.-Cumulative curves of horizontal permeability of all Madison Limestone samples. Permeability is plotted on a lognormal probability scale.

porosity in these rocks were intercrystalline, there would probably be a good negative correlation between porosity and size and sorting, because pore size and configuration would depend chiefly on crystal size and arrangement (Wardlaw, 1979). One of the main reasons for no correlation is that numerous other pore types, such as moldic and fracture, exist in these rocks, and their size, number, and distribution are totally unrelated to the size or arrangement of the dolomite crystals.

The plot of mean dolomite crystal size versus horizontal permeability in figure 22 shows a poor correlation

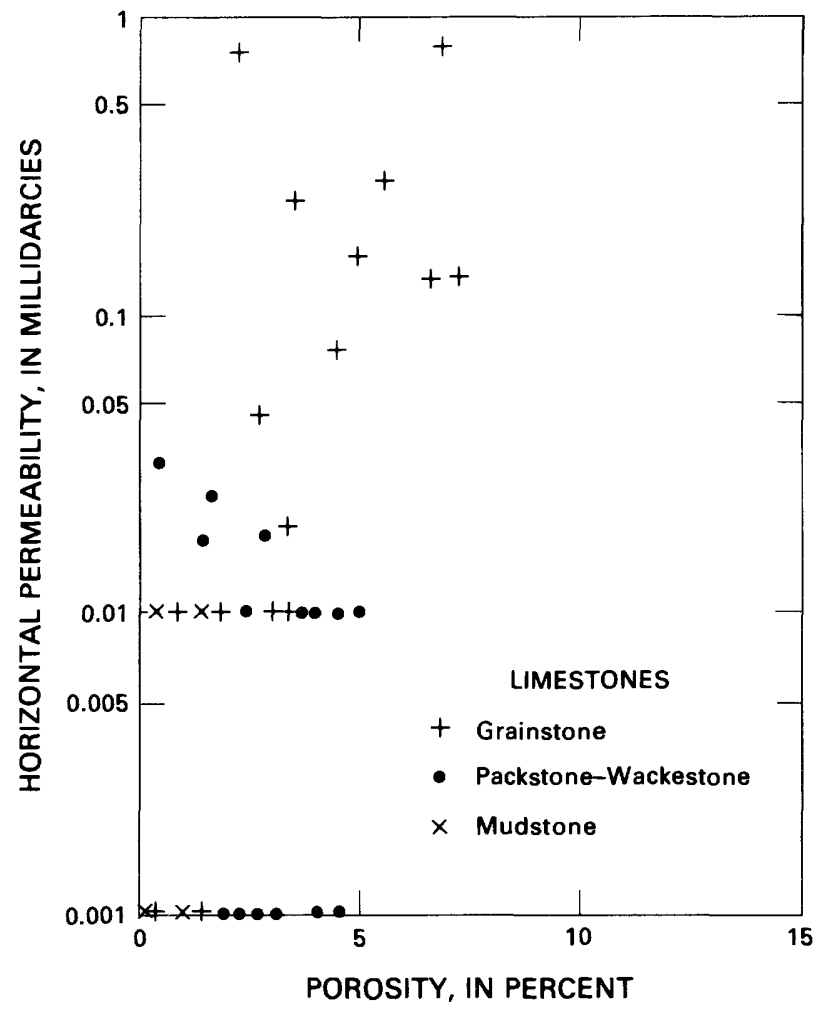

FIGURE 17.-Porosity-permeability characteristics of limestones in the Madison Limestone.

between the two, indicating a general decrease in permeability as size decreases. The suggested explanation for this decrease is that permeability is mainly controlled by the percent of intercrystalline pores, and the size of those pores is dependent on dolomite crystal size. That is, as the size of crystals decreases, so does the size of the pores and pore throats, which leads to increased capillary trapping and permeability reduction. To be sure, several points on this diagram do not fit this explanation. For example, some of the points in the $6 \phi$ to $9 \phi$ range have permeability values equivalent to those in $3 \phi$ to $6 \phi$ range. Careful reexamination of these samples reveals that the "high" values result from fracturing. Points in the $3 \phi$ to $6 \phi$ range that have low permeability values result mainly from anhydrite filling pores and pore throats. Secondary calcite within pores also has the same effect. The marked decrease in dolomite porosity with increasing percentage of anhydrite is clearly demonstrated in figure 23.

Other factors also influence porosity and permeability of dolomites. One such influence is probably compaction, which is related to depth of burial. The porosity increase could also be related to the opportunity for more fresh water in the system at shallower depths. A plot of porosity versus depth for crystalline dolomites (fig. 24) 


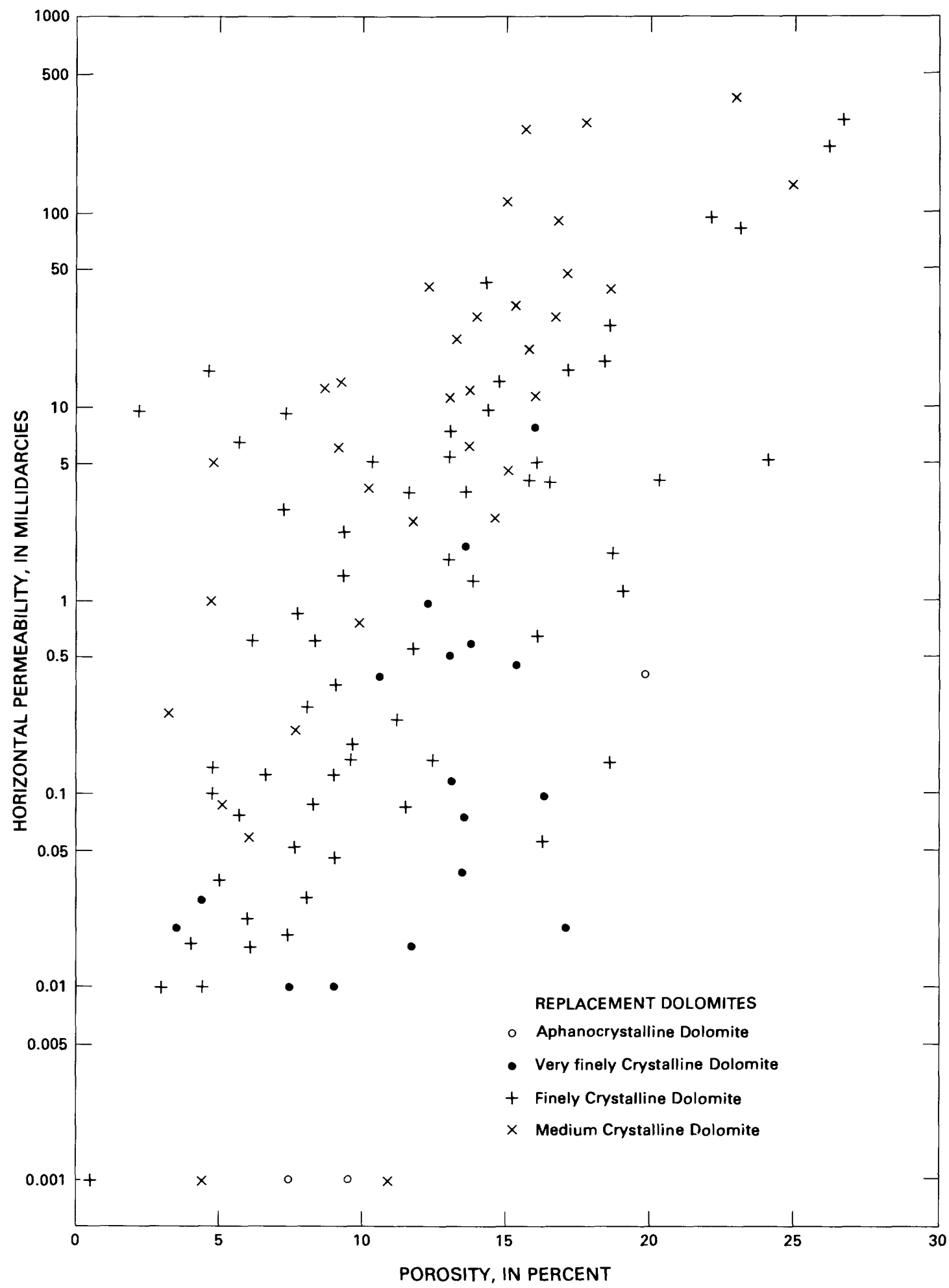

FIGURE 18.-Porosity-horizontal permeability characteristics of Madison Limestone replacement dolomites. 


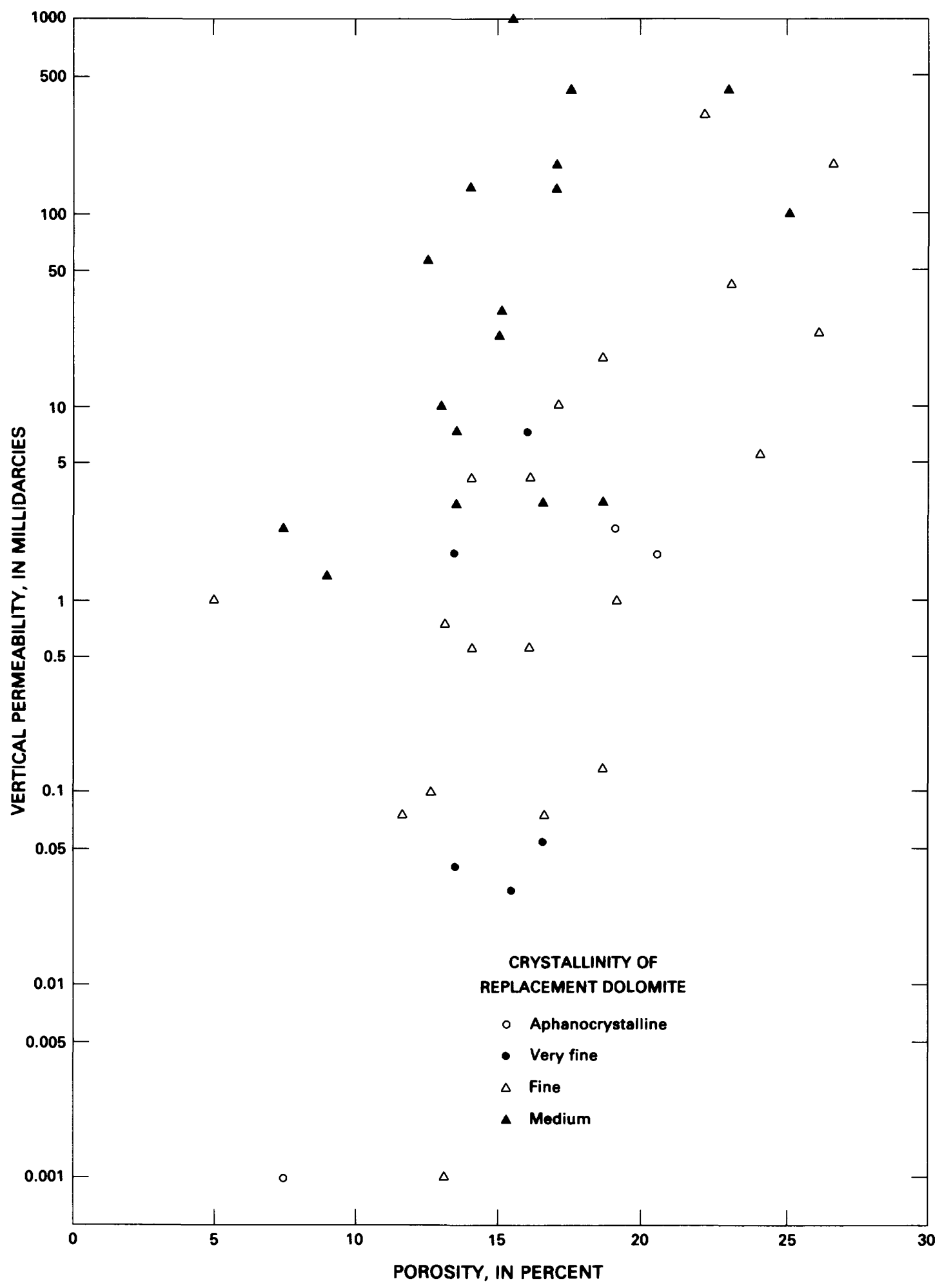

FIGURE 19.-Porosity-vertical permeability characteristics of Madison Limestone replacement dolomites 


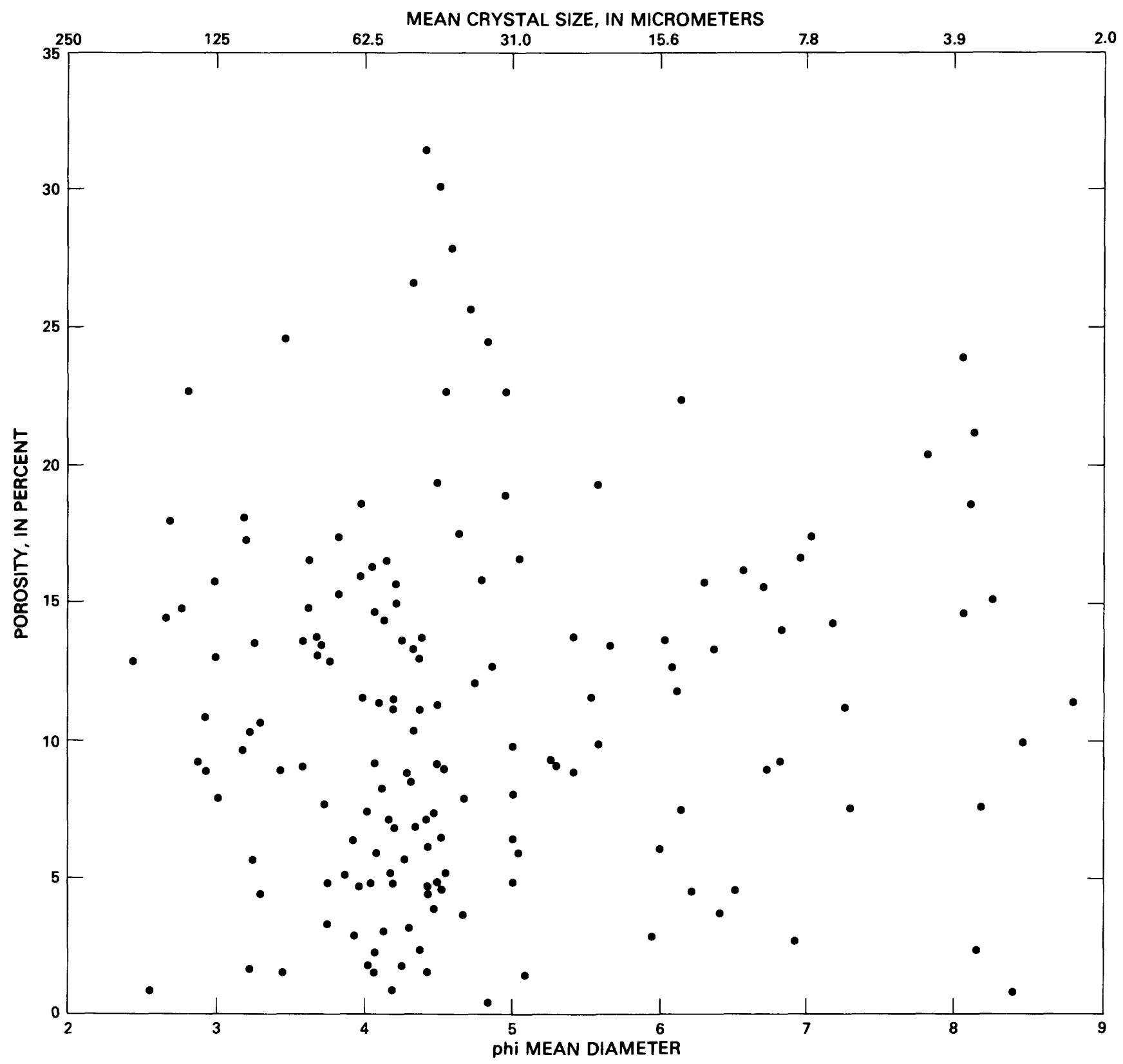

FIGURE 20.-Scatterplot of mean dolomite crystal size versus porosity for Madison Limestone crystalline dolomites.

shows that porosity is generally larger at shallow depths; however, below 4,000 ft in wells 1 and 2, there is little difference in porosity values. The variation of porosity with depth is not due to differences in dolomite types (that is, grain size and fabric), as the proportion of each type within the three wells is approximately equal. Part of the variation is related to the greater anhydrite content of dolomites in wells 2 and 3 (pl. 1, 2, and 3). Percentages of terrigenous insoluble residue plotted against porosity and permeability show no correlation. Apparently, the percentage of terrigenous residue is so low in these dolomites that it has no influence on porosity and permeability.

\section{CONCLUSIONS}

Six major rock types are recognized in the Madison Limestone within cored intervals of the three test wells. Dolomite forms about 67 percent of the total and limestone (grainstone, packstone-wackestone, and mudstone) about 20 percent. The remainder consists of anhydrite, carbonate breccia, and chert. 


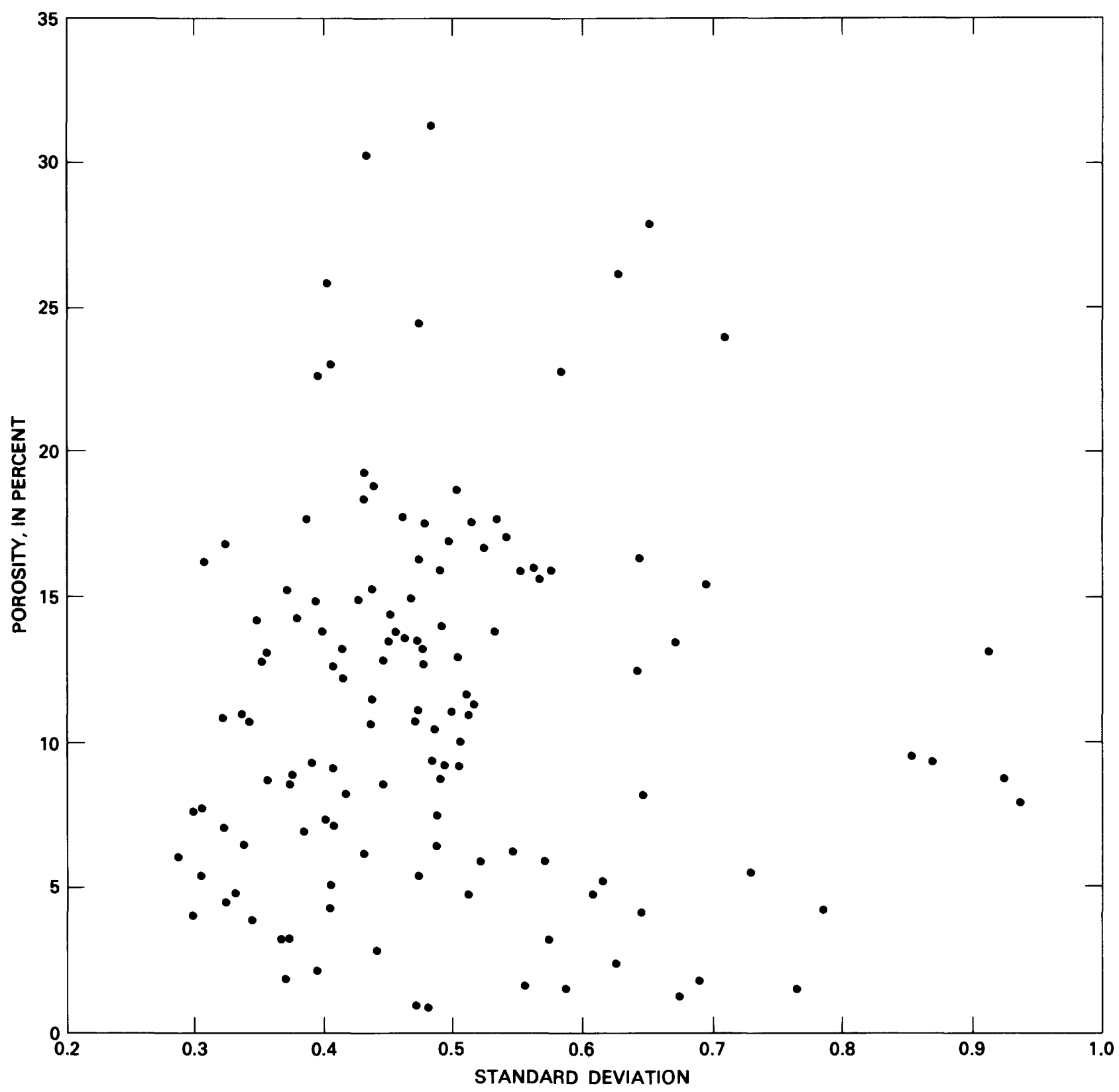

FIGURE 21.-Scatterplot of standard deviation (sorting) of dolomite crystal size versus porosity for Madison Limestone dolomites.

Dolomite can be subdivided into two groups: those of penecontemporaneous intertidal-supratidal syngenetic origin and crystalline diagenetic dolomites of replacement origin. Fine-grained penecontemporaneous rocks are cyclically arranged with beds of nodular anhydrite and both formed beneath a sabkha surface by reflux of dense brines. Subsequent movement of the brines in a downward, and possibly seaward, direction dolomitized older shallow-water limestones that had previously been cemented. Cyclic recurrence of sabkha cycles through space and time is believed to have caused the wide- spread dolomitization of most shallow-water Madison Limestone carbonates.

Crystalline dolomites not associated with evaporites may have formed by some sort of meteoric water-sea water mixing process in the subsurface shoreline environment. These dolomites formed by recrystallization of mud-rich limestones, chiefly biomicrites, biopelmicrites and micrites.

The Madison Limestone in wells 1,2 , and 3 is of shoreline or shallow-water shelf origin. Grainstones, chiefly oosparites, and biopelsparites formed in high-energy, 


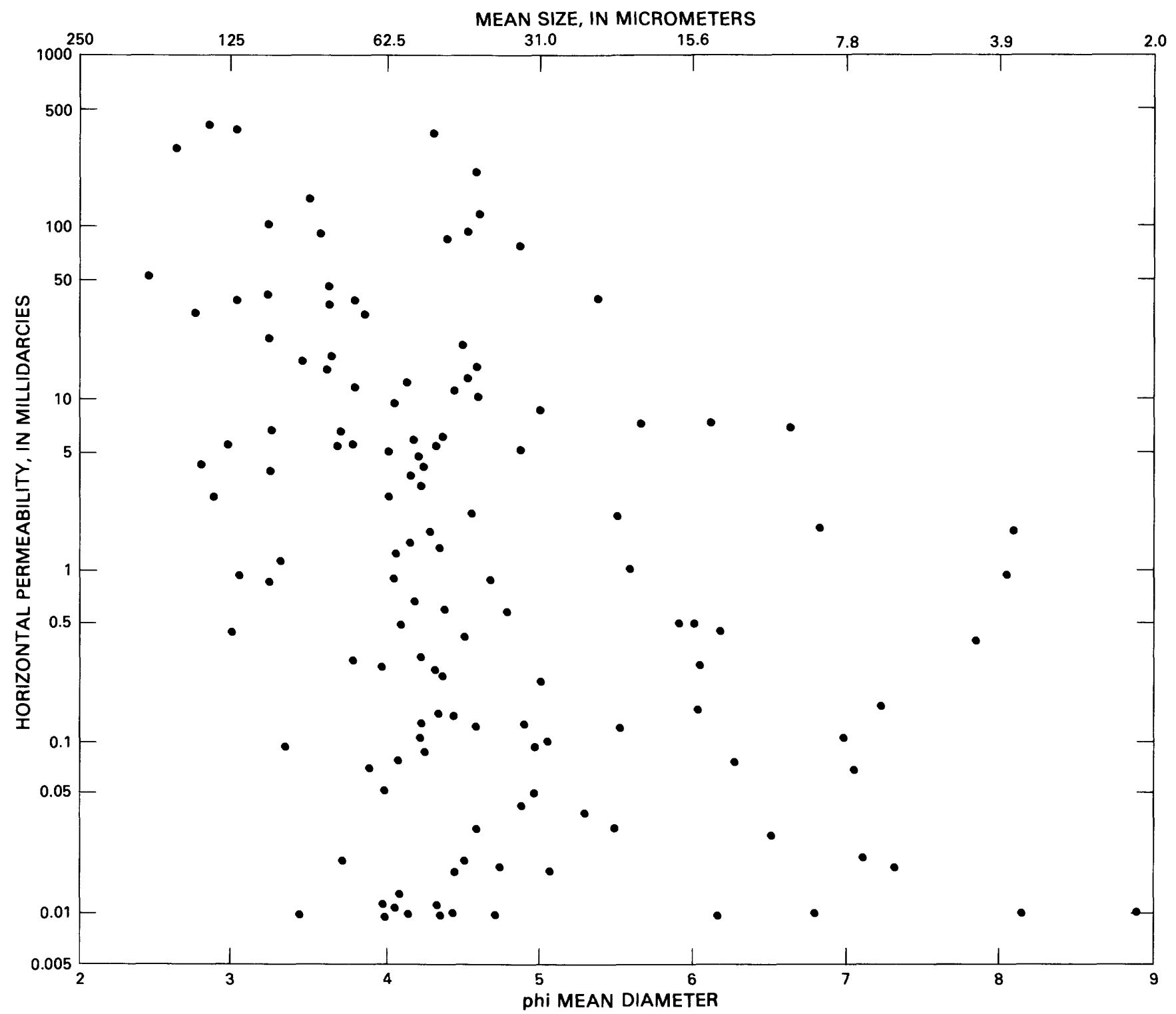

FIGURE 22.-Plot of mean dolomite crystal size against horizontal permeability for Madison Limestone crystalline dolomites.

very shallow-water environments. Mud-rich carbonates formed in low-energy, shallow-water shelf environments below wave base. Early diagenetic fresh-water cementation greatly reduced porosity and permeability in all limestone types.

Carbonate breccias occur at the top of the Madison Limestone in all three wells; they formed by collapse resulting from solution of underlying evaporites. The uppermost breccias are of post-Madison, pre-Amsden age. The lower breccia zones (M-7 to M-8.5 in test well 1 , and M-8.5 to M-12 in test well 2) contain no Amsden sediments and probably formed in pre-Amsden time. Formation of the breccias followed lithificaton, but may represent a period of subaerial exposure during the individual chronstratigraphic depositional periods.
More study is needed to more closely date the period of breccia formation.

Chert occurs as small nodules throughout the Madison Limestone, and as beds near the base of the Madison Limestone in test well 3. Both types replaced preexisting limestones or dolomites; the silica probably originated from dissolution of sponge spicules, possibly from radiolarians, or from a ground-water source.

Crystalline dolomite is the only abundant rock type in wells 1,2 , and 3 that has high enough porosities and permeabilities to provide significant yields of water. Medium and finely crystalline dolomites show the best values of porosity and permeability, because they have high percentages of intercrystalline and moldic pores that are well connected. Fracture, vug, and channel are 


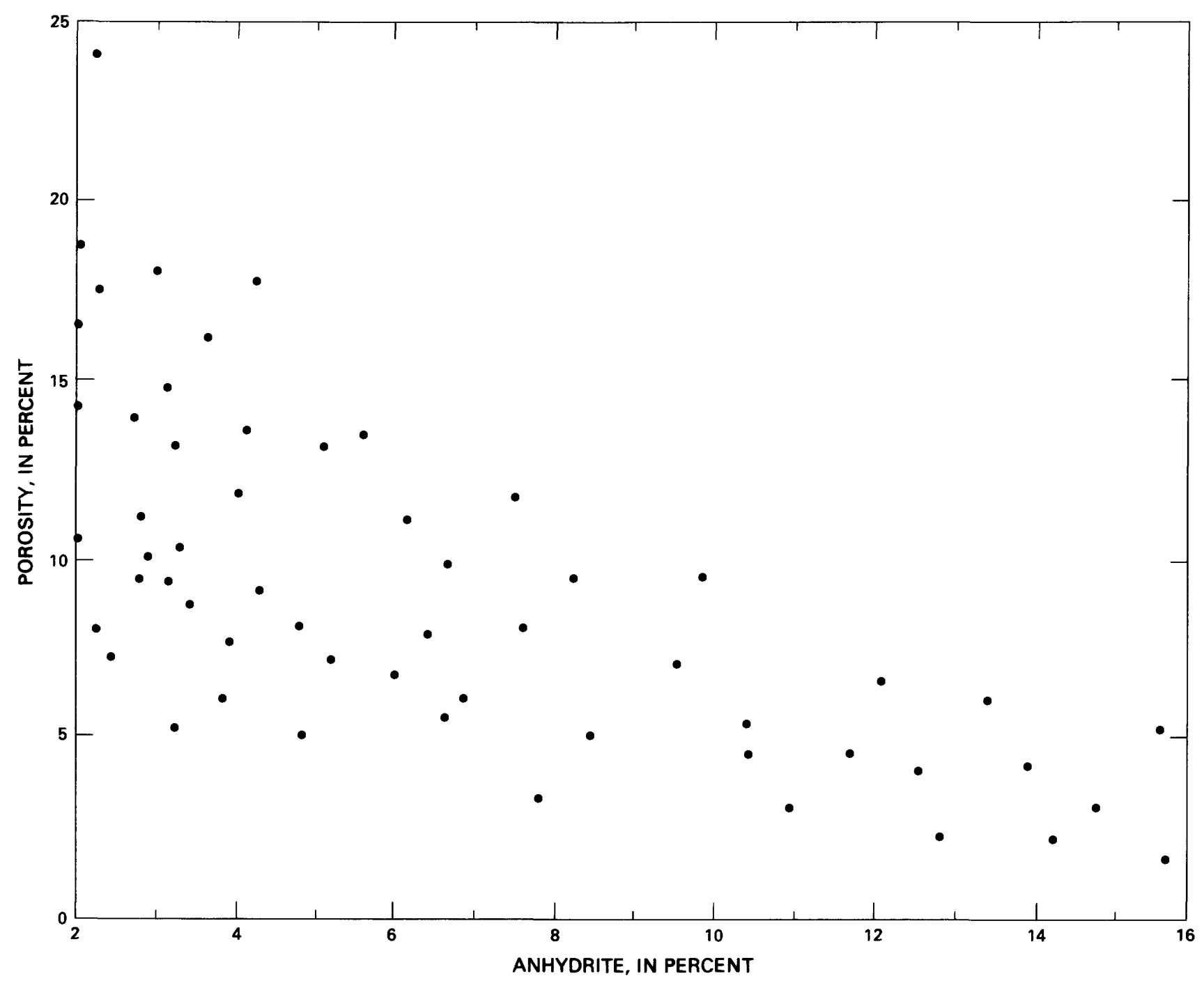

FIGURE 23.-Plot of percent anhydrite versus percent porosity for Madison Limestone crystalline dolomites.

minor dolomite porosity types. Clogging of pores by secondary anhydrite and calcite can significantly reduce porosity and permeability.

\section{REFERENCES}

Bathurst, R. G. C., 1971, Carbonate sediments and their diagenesis: Amsterdam, Elsevier Publishing Company, $620 \mathrm{p}$.

Blankennagel, R. K., Howells, L. W., Miller, R. W., and Hansen, C. V., 1979, Preliminary data for Madison Limestone test well 3, NW1/4 $\mathrm{SE}^{1 / 4} \mathrm{sec}$ s5, T. 2 N., R. 27 E., Yellowstone County, Montana: U.S. Geological Survey Open-File Report 79-745, 201 p.

Blankennagel, R. K., Miller, W. R., Brown, D. L., and Cushing, E. M., 1977, Report on preliminary data for the Madison Limestone test well no. 1, NE $1 / 4$ SE1/4 sec. 15, T. 47 N., R. 65 W., Crook County, Wyoming: U.S. Geological Survey Open-File Report 77-164, 97 p.

Brown, D. L., Blankennagel, R. K., Busby, J. F., and Lee, R. W., 1977, Preliminary data for Madison Limestone test well 2, $\mathrm{SE}^{1 / 4} \mathrm{SE}^{1 / 4}$ sec. 18, T. 1 N., R. 54 E., Custer County, Montana: U.S. Geological Survey Open-File Report 77-863, 135 p.
Campbell, C. V., 1967, Lamina, laminaset, bed and bedset: Sedimentology, v. 8, p. 7-26.

Choquette, P. W., and Pray, L. C., 1970, Geologic nomenclature and classification of porosity in sedimentary carbonates: American Association of Petroleum Geologists Bulletin, v. 54, p. 207-250.

Craig, L. C., 1972, Mississippian system, in Mallory, W. W., ed., Geologic atlas of the Rocky Mountain region: Denver, Colorado, Rocky Mountain Association of Geologists, p. 100-110.

Davies, G. R., 1979, Dolomite reservoir rocks: processes, controls, porosity development, in Geology of carbonate porosity: American Association of Petroleum Geologists Continuing-Education Course-Note Series 11, p. C1-C17.

Davis, S. N., 1969, Porosity and permeability of natural materials, in DeWeist, R. J. M., ed., Flow through porous media: New York, Academic Press, p. 53-59.

Dunham, R. J., 1962, Classification of carbonate rocks according to depositional texture, in Ham, W. E., ed., Classificaton of carbonate rocks: American Associaton of Petroleum Geologists Memorandum 1, p. 62-84. 


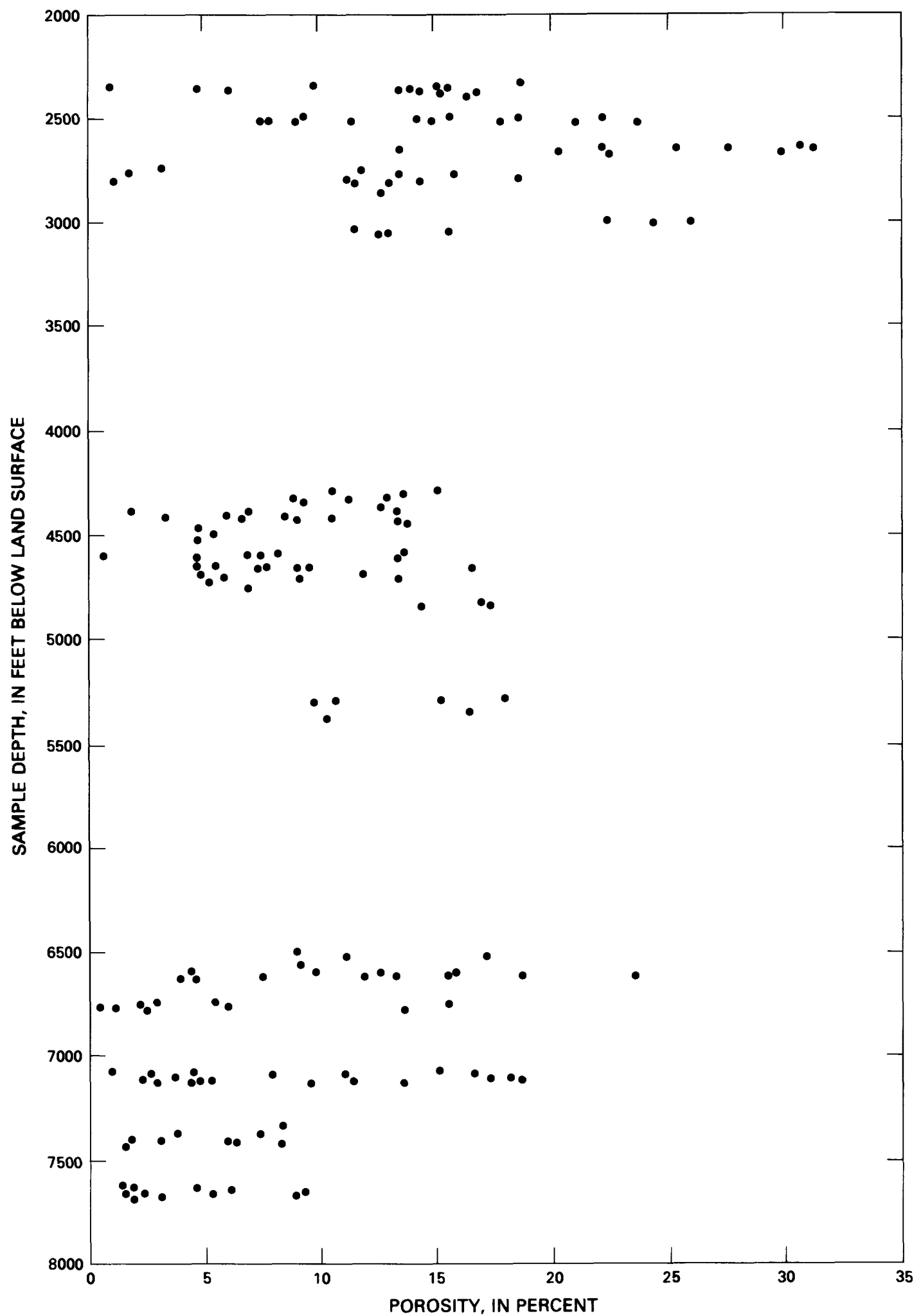

FIGURE 24.-Plot of percent porosity versus depth in feet below ground surfaces for Madison Limestone crystalline dolomites. 
Flügel, Erik, Franz, H. E., and Ott, W. F., 1968, Review on electron microscope studies of limestones, in Müller, G., and Friedman, G. M., editors, Recent developments in carbonate sedimentology in central Europe: New York, Springer-Verlag, p. 85-97.

Folk, R. L., 1962, Spectral subdivisions of limestone types, in Ham, W. E., ed., Classification of carbonate rocks: American Association of Petroleum Geologists Memorandum 1, p. 62-84.

Folk, R. L., and Land, L. S., 1975, $\mathrm{Mg} / \mathrm{Ca}$ ratio and salinity: two controls over crystallization of dolomite: American Association of Petroleum Geologists Bulletin, v. 59, p. 60-68.

Folk, R. L., and Pittman, J. S., 1971, Length-slow chalcedony: a new testament for vanished evaporites: Journal of Sedimentary Petrology, v. 41, p. 1045-1058.

Friedman, G. M., 1965, Terminology of crystallization textures and fabrics in sedimentary rocks: Journal of Sedimentary Petrology, v. 35, p. $643-655$.

Ginsburg, R. N., and James, N. P., 1974, Holocene carbonate sediments of continental shelves, in Burk, C. A., and Drake, C. L., eds., The geology of continental margins: New York, SpringerVerlag, p. 137-155.

Grose, L. T., 1972, Tectonics, in Geologic atlas of the Rocky Mountain region: Denver, Colorado, Rocky Mountain Association of Geologists, p. 35-44.

Hanshaw, B. B., Back, William, and Deike, R. G., 1971, A geochemical hypothesis for dolomitization of ground water: Economic Geology, v. 66, p. 710-724.

Hanshaw, B. B., Busby, J. F., and Lee, R. W., 1978, Geochemical aspects of the Madison aquifer system, in Williston Basin Symposium Proceedings: Billings, Montana, Twenty-fourth Annual Conference, Montana Geological Society, September 1978, p. 385-389.

Ingram, R. L., 1954, Terminology for the thickness of stratification and parting units in sedimentary rocks: Geological Society of America Bulletin, v. 65, p. 937-938.

Jenks, S. E., and Wilson, J. L., 1972, Diagenesis of oolites in Lodgepole Formation (Mississippian), central Montana [abs.]: American Association of Petroleum Geologists Bulletin, v. 56, p. 630-631.

Kendall, A. C., 1979, Facies models 13. Continental and supratidal sebkha evaporates, in Walker, R. G, ed., Facies models: Geoscience Canada, Reprint Series 1, p. 145-157.

Kinsman, D. J. J., 1969, Modes of formation, sedimentary associations, and diagnostic features of shallow-water and supratidal evaporites: American Association of Petroleum GeologistsBulletin, v. 53, p. $830-841$.

Land, L. S., Salem, M. R. I., and Morrow, D. W., 1975, Paleohydrology of ancient dolomites: geochemical evidence: American Association of Petroleum Geologists Bulletin, v. 59, p. 1602-1625.

Lucia, F. J., 1962, Diagenesis of a crinoidal sediment: Journal of Sedimentary Petrology, v. 32, p. 848-865.

1972, Recognition of evaporite-carbonate shoreline sedimentation, in Rigby, J. K., and Hamblin, W. K., eds., Recognition of ancient sedimentary environments: Society of Economic Paleontologists and Mineralogists Special Publication 16, p. 160-191.

McCaleb, J. A., and Wayhan, D. A., 1969, Geologic reservoir analysis, Mississippian Madison Formation, Elk Basin Field, WyomingMontana: American Association of Petroleum Geologists Bulletin, v. 53, p. 2094-2113.

Middleton, G. V., 1961, Evaporite solution breccias from the Mississippian of southwest Montana: Journal of Sedimentary Petrology, v. 31, p. 189-195.

Milliken, K. L., 1979, The silicified evaporite syndrome - two aspects of silicification history of former evaporite nodules from southern
Kentucky and northern Tennessee: Journal of Sedimentary Petrology, v. 49, p. 245-256.

Murray, R. C., 1960, Origin of porosity in carbonate rocks: Journal of Sedimentary Petrology, v. 30, p. 59-84.

1964, Origin and diagenesis of gypsum and anhydrite: Journal of Sedimentary Petrology, v. 34, p. 512-523.

Murray, R. C., and Lucia, F. J., 1967, Cause and control of dolomite distribution of rock selectivity: Geological Society of America Bulletin, v. 78, p. 21-35.

Nordquist, J. W., 1953, Mississippian stratigraphy of northern Montana, in Billings Geological Society Guidebook: 4th Annual Field Conference, September 1953, p. 68-82.

Powers, R. W., 1962, Arabian Upper Jurassic carbonate reservoir rocks, in Ham, W. E., ed., Classification of carbonate rocks-a symposium: American Association of Petroleum Geologists Memoir 1, Tulsa, Oklahoma, p. 122-192.

Purser, B. H., and Evans, G., 1973, Regional sedimentation along the Trucial Coast, in Purser, B. H., ed., The Persian Gulf: New York, Springer-Verlag, p. 211-232.

Roberts, A. E., 1966, Stratigraphy of Madison Group near Livingston, Montana, and discussion of karst and solution-breccia features: U.S. Geological Survey Professional Paper 526-B, p. B1-B23.

Sando, W. J., 1974, Ancient solution phenomena in the Madison Limestone (Mississippian) of north-central Wyoming: U.S. Geological Survey Journal of Research, v. 2, no. 2, p. 133-141.

Scholle, P.A., 1978, A color illustrated guide to carbonate rock constituents, textures, cements, and porosities: American Association of Petroleum Geologists Memoir 27, 241 p.

Shearman, D. J., 1978, Evaporites of coastal sabkhas, in Dean, W. E., and Schreiber, B. C., eds., Marine evaporites: Society of Economic Paleontologists and Mineralogists Short Course Lecture Notes No. 4, p. 6-42.

Siedlecka, A., 1972, Length-slow chalcedony and relicts of sulphates - evidences of evaporitic environments in the upper Carboniferous and Permian beds of Bear Island, Svalbard: Journal of Sedimentary Petrology, v. 42, p. 812-816.

Stanton, R. J., Jr., 1966, The solution brecciation process: Geological Society of America Bulletin, v. 77, no. 8, p. 843-847.

Stone, D. S., 1969, Wrench faulting and Rocky Mountain tectonics: Wyoming Geological Association Earth Sciences Bulletin, June, v. 2 , no. 2, p. 27-41.

Thayer, P. A., and Textoris, D. A., 1977, Faunal and diagenetic controls of porosity and permeability in Tertiary aquifer carbonates, North Carolina: Raleigh, North Carolina, North Carolina Department of Natural Resources and Community Development, Division of Earth Resources Special Publication 7, 35 p.

Till, R., 1978, Arid shorelines and evaporites, in Reading, H. G., ed., Sedimentary environments and facies: New York, Elsevier Scientific Publishing Company, ch. 8, p. 178-206.

Wardlaw, N. C., 1979, Pore systems in carbonate rocks and their influence on hydrocarbon recovery efficiency, in Geology of carbonate porosity: American Association of Petroleum Geologists Continuing-Education Course-Note Series 11, p. E1-E24.

Weyl, P. K., 1960, Porosity through dolomitization: Conservation-ofmass requirements: Journal of Sedimentary Petrology, v. 30, p. $85-90$.

Wilson, J. L., 1975, Carbonate facies in geologic history: New York, Springer-Verlag, $471 \mathrm{p}$.

Wood, G. V., and Armstrong, A. K., 1975, Diagenesis and stratigraphy of Lisbourne Group Limestone of the Sadlerochit Mountains and adjacent areas, northeastern Alaska: U.S. Geological Survey Professional Paper 857, 47 p., 12 plates. 